\title{
Regional Subsidies and Industrial Prospects of Lagging Regions
}

\author{
by \\ Alexandre Carvalho \\ DIRUR, Instituto de Pesquisa Econômica Aplicada (IPEA) \\ alexandre.ywata@ipea.gov.br \\ Somik V. Lall \\ Development Research Group, The World Bank \\ slall1@worldbank.org \\ Christopher Timmins \\ Department of Economics, Duke University \\ timmins@econ.duke.edu
}

\begin{abstract}
Large and sustained differences in economic performance across regions of developing countries have long provided motivation for fiscal incentives designed to encourage firm entry in lagging areas. Empirical evidence in support of these policies, however, has been weak at best. This paper undertakes a direct evaluation of the most prominent fiscal incentive policy in Brazil, the Fundos Constitucionais de Financiamento (Constitutional Funds). In doing so, we exploit valuable features of the Brazilian Ministry of Labor's RAIS data set to address two important elements of firm location decisions that have the potential to bias an assessment of the Funds: (i) firm "family structure" (in particular, proximity to headquarters for vertically integrated firms), and (ii) unobserved spatial heterogeneity (with the potential to confound the effects of the Funds). We find that the pull of firm headquarters is very strong relative to the Constitutional Funds for vertically integrated firms, but that, with non-parametric controls for time invariant spatial heterogeneity, the Funds provide statistically and economically significant incentives for firms in many of the targeted industries.
\end{abstract}

JEL Classification: L22, R12, R58

World Bank Policy Research Working Paper 3843, February 2006

The Policy Research Working Paper Series disseminates the findings of work in progress to encourage the exchange of ideas about development issues. An objective of the series is to get the findings out quickly, even if the presentations are less than fully polished. The papers carry the names of the authors and should be cited accordingly. The findings, interpretations, and conclusions expressed in this paper are entirely those of

the authors. They do not necessarily represent the view of the World Bank, its Executive Directors, or the countries they represent. Policy Research Working Papers are available online at http://econ.worldbank.org.

\section{Acknowledgements}

This research has been funded a World Bank Research Grant "Assessing the Impacts of Alternate Policies for the Development of Lagging Regions.” We have benefited from discussions with Mansueto Alemeida, Carlos Azzoni, Pedro Cavalcanti Ferreira, Ken Chomitz, Uwe Deichmann, Marianne Fay, Mila Freire, Marcelo Piancastelli and Zmarak Shalizi. 


\section{Introduction}

Sub-national disparities in economic performance and living standards are large and often sustained in many countries. Prospects for lagging regions in developing counties are of particular concern as these areas are not just characterized by lower relative incomes and standards of living, but may in fact be home to significant incidence of absolute poverty. Local populations may be stuck in so-called spatial poverty traps, in which poor infrastructure and resource endowments limit access to educational, social, and economic opportunities (Jalan and Ravallion 1997).

In theory, market dynamics in a system with increasing returns to scale will generally favor corner solutions with full out-migration except under conditions of limited mobility. Because this condition is so prevalent in reality, many governments have opted for interventions to offset some of these market pressures. This has created the policy tension between the market solution of out-migration or labor flows (i.e., "moving people to jobs”), and the intervention of promoting capital flows, including fiscal transfers designed to support incomes or to subsidize the creation of jobs and the extension of credit (i.e., “moving jobs to people”).

In many countries, decades of spatially explicit interventions have provided little evidence that these policies can lead to improved economic performance and welfare enhancements in lagging regions. In addition, it is also difficult to show whether regional incentive policies enhance national welfare. Is it welfare enhancing to move a firm from one location to another and then pay for its re-location costs? Do these policies encourage any new entry, or do they simply result in the spatial re-allocation of firms that would have entered anyway? In this paper, we outline a strategy to evaluate the impacts of spatially 
explicit development programs - using Brazilian data to implement the initial stages of the analysis, and plotting a course for continued research.

\section{Regional Disparities in Brazil}

Brazil has a long history of regional disparities. The Brazilian Northeast has historically been the poorest region in the country, with regional per capita incomes being about one half of those in the prosperous Southeast (Lall and Shalizi, 2003). Figure 1 describes the $25^{\text {th }}, 50^{\text {th }}$, and $75^{\text {th }}$ percentiles of the Brazilian monthly income distribution by state based on 1991 demographic census data. The highest median per capita household income (\$79.93 per month in Goias) is nearly four times larger than that of the lowest median per capita household income state (\$20.49 per month in Maranhao). Eight states report median per capita household incomes of less than $\$ 1$ per day, seven of which are located in the country's Northeast region. Of the ten poorest states in the country, eight are in the Northeast, and two in the North region (Azzoni et. al, 2002). These large per capita income differences across regions are, moreover, surprisingly stable over very long periods. Per capita income in the Southeast was 2.9 times that of the Northeast in 1939 and 2.8 times in 1992 (World Bank, 1998).

Beyond purely economic indicators, social indicators in the Northeast region are also considerably worse than the national average. The illiteracy rate is at least three times higher than that of São Paulo, the child mortality rate is twice as large as that of the Southeast (54.5 per thousand in the Northeast compared to 26.3 per thousand in the Southeast), life expectancy four years shorter, and income inequality is much worse (Ferreira, 2004). Inequality, measured by the Theil coefficient is 0.80 for Ceará, Bahia and 
Pernambuco, in contrast to 0.55 for the state of São Paulo (Ferreira, 2000). Fifty percent of the Northeast population lives in poverty.

\section{Regional Development Policies in Brazil}

Large regional disparities between the Northeast and the rest of the country (coupled with a severe drought in 1958) stimulated the Brazilian government to develop explicit policies for that region (Baer, 1995). The strategy was to establish an autonomous center of manufacturing expansion by attracting "dynamic" and high-growth industries, such as those in metallurgy, machinery, electrical equipment and paper products (World Bank, 1987). Instruments such as fiscal incentives, transfers, and direct expenditures in the form of industrial land and infrastructure were widely used to attract economic activity (Goldsmith and Wilson, 1991; Markusen, 1994; World Bank, 1987).

Financial outlays from the central government in Brazil to support spatially explicit programs have been estimated to be US $\$ 3$ to 4 billion per annum in recent years (Ferreira 2004). The estimated cost of tax breaks and associated regional development programs (excluding the Zona Franca de Manaus) in 2002 was estimated at almost US \$900 million (Secretaria da Receita Federal, 2003). Tax credits directed to the Zona Franca de Manaus are estimated to be US $\$ 1.2$ billion in 2003 alone. Investment incentive programs for the North and the Northeast, funded by income tax deductions, averaged more than 600 million dollars a year between 1995 and 2000, before they were shut down for accusations of mismanagement.

The main objective of our paper is to examine the effect of regional subsidies on

industrial prospects of lagging regions in Brazil. There have been several reviews of 
spatially explicit programs in Brazil and also in other countries, with the general conclusion that these initiatives have very small effects. For instance, Ferreira (2004) claims that much of the GDP per capita growth in the Northeast (and convergence with the South and Southeast) can be attributed to out-migration rather than local employment creation, and that welfare gains from these interventions are limited as most of the population that benefited from the jobs created came from other parts of Brazil. He also finds that most of the convergence in per capita incomes across Brazilian regions occurred over the period 1970-1985, before the initiation of the Constitutional Funds. [Ellery and Ferreira (1996)] Maia Gomes (2002) finds that, while GDP did grow throughout Brazil over the period 1960 to the present, it did not grow as fast in the Northeast (the focus of most regional policies) as in the rest of the country. Ferreira (2004) finds similar results focusing only on the period 1990-2000 (i.e., the first decade of the Constitutional Fund program).

Each of these papers looks for indirect evidence of regional policies’ impacts on economic outcomes (e.g., GDP or GDP growth rates). The problem with this approach is that these outcomes are affected by a multitude of factors besides regional policy (e.g., macroeconomic shocks), some of which may influence certain parts of the country more than others. The relevant question is not whether the Northeast grew faster than the rest of the country during the Constitutional Fund program, but rather whether it grew faster than it would have in the absence of the program. This is a very difficult question to answer. In this paper, we instead conduct a more direct evaluation of the impact of the Constitutional Funds. In particular, we address a relatively limited question - did the Constitutional Funds successfully induce entry by firms into Brazil’s lagging regions? Answering this 
question necessarily precedes and motivates further work on measuring the welfare impacts of the policy (which we outline in the conclusion). In addressing this question, we account for two features of the firm location problem that have the potential to bias estimates if ignored. First, we non-parametrically account for regional attributes such as amenities, infrastructure, local public goods, and natural endowments. Since regional incentives are allocated to compensate for inter-regional differentials in local characteristics, it is imperative to adequately account for these factors in examining the contribution of these programs. Otherwise, there is a tendency to systematically understate their value. Second, our empirical analysis makes use of a linked headquarter-branch plant panel data set, which allows us to consider the role of intra-firm considerations in the location decisions of vertically integrated firms. If firms tend to locate branch plants in close proximity to their headquarters, and if those headquarters are disproportionately located in unsubsidized areas, this could be mis-interpreted as a failure of the fiscal incentive. While the empirical application focuses on Brazil, the estimation strategy outlined in the paper has broader applicability and can be used to examine similar issues across countries.

Our main findings are that subsidized credit offered to firms via the CF's has worked in terms of industrialization in the Northeast. At the same time, we find that pull of the headquarters has a much bigger effect on entry than the CF's for the minority of vertically integrated firms (i.e., with headquarters). This implies that, for vertically integrated industries, firm structure needs to play a part in the CF - i.e., reform to promote entry by headquarter firms into lagging regions. In more footloose sectors, such reforms would not be necessary. 
The remainder of this paper is organized into five sections. In Section 2, we discuss the design and allocation of the CF's. Section 3 describes the data, and Section 4 discusses our estimation strategy. Section 5 describes the main findings and Section 6 concludes.

\section{Allocation of Brazilian Constitutional Funds}

National governments in many countries have a long history of using fiscal incentives to stimulate the growth potential of lagging sub-national regions. These spatially explicit programs are designed to compensate for location specific disadvantages, such as transport and logistics costs, infrastructure conditions, factor price differentials and lower levels of public services and amenities. A detailed discussion on various regional development programs in Brazil is provided in Ferreira (2004) and World Bank (2005). Explicit spatial policies in Brazil include three sets of instruments which target private sector development through various kinds of subsidies: (a) fiscal incentive programs such as those administered by SUDENE, SUDAM, and the Zona Franca de Manaus (Manaus Free Trade Zone); (b) subsidized credit channeled through the CF's, which has become one of the most important instruments of spatial policy in Brazil; (c) and regional development banks, such as Banco do Nordeste do Brazil (BNB).

The focus of our analysis is on the effectiveness of subsidized credit channeled through the CF's. In 1989, the Brazilian Congress instituted three Constitutional Investment Funds (Fundos Constitucionais de Financiamento) for the Northeast (FNE), the Center-West (FCO), and the North (FNO). The main aim of these funds was to stimulate economic and social development in these regions by extending credit to local 
entrepreneurs. Preferential treatment was provided to micro- and small-scale agricultural producers and small-scale manufacturing to encourage the use of local raw materials and labor. Sixty percent of the outlays for the CF's were allocated to the Northeast, and 20 percent were allocated to each of the North and the Center West. Funds are transferred from the National Treasury to the Ministry of Integration (“Ministério da Integração”), which later reallocates them to the operating banks - the Banco do Nordeste (FNE), Banco da Amazônia (FNO) and Banco do Brasil (FCO). The CF’s are financed by receipts from income taxes and taxes on industrial products.

Interest rate subsidies are the main incentive offered through the CF's. While market interest rates offered to private firms are currently more than $45 \%$, the CF's offer credit at $8.75 \%$ to non-agricultural micro firms; $10 \%$ to small firms, $12 \%$ to medium sized firms; and $14 \%$ to large enterprises. Interest rates are even lower for comparable agro producers: $6 \%$ for mini-producers, $8.75 \%$ for small to average and $10.75 \%$ for large ones. These interest rates were negative in real terms in 2002, when inflation was $12.5 \%$. Rates offered to individual producers varied by sector, investment size, and credit record of the borrower. Between 1989 and 2002, more than US \$10 billion were provided in subsidized loans, which is about $0.8 \%$ of the total GDP of the 3 regions per year (Ferreria 2004).

\section{Data}

We now describe the data used in the econometric exercises. We created a working database that maps the spatial entry decisions of new establishments in Brazil, with the goal of learning how the CF's affect those decisions. The main source of information is 
the RAIS micro data, provided by the Labor Ministry. ${ }^{1}$ We study the effects of the CF's on entry by firms in 18 sectors (11 manufacturing, 7 service) into 265 "urban agglomerations” (see description below) over the years 1993-2001. ${ }^{2}$

The RAIS database contains a vast range of information for all economic establishments in the formal sector in Brazil from 1986 onward. For each establishment in this database, we have annual information on the number of employees at the beginning and end of each year; total salaries and wages; in which municipality the company is located; as well as the establishment's economic activity according to several industry classifications. To avoid problems caused by a large number of establishments with very few employees, we limit our analysis to establishments with no fewer than 10 employees. This paper is the first research project to use the RAIS data to study firm geography and the effectiveness of fiscal incentives.

As discussed above, one important piece of information in the estimated models is the composition and location of the relatives for each establishment. To uncover the composition of each family of establishments (parent and sibling establishments), which constitutes a firm, we make use of the establishment identification number, hereafter CNPJ. The CNPJ has 14 digits and is the official identification number for all productive units in the formal sector. The first 8 digits of the CNPJ indicate the company (or family) of each establishment. The next 4 digits indicate the position of the establishment in the family. For example, “0001” indicates the first establishment in the company, which is assumed in this paper to be the company headquarters. The other establishments in the company are given sequential codes, so that the second establishment receives "0002”, the

\footnotetext{
${ }^{1}$ The RAIS data was used under a cooperation agreement between the Labor Ministry and the Institute of Applied Economic Research (IPEA).
} 
third establishment receives “0003”, and so on. Some of the companies are composed by a single establishment, which receives the 4-digit code "0001". ${ }^{3}$ The last two digits of the CNPJ correspond to the establishment economic sector, and they work more as a confirmation code. Therefore, we use the first 12 digits of the CNPJ to extract the establishment composition of each company.

To summarize, there are three reasons why the RAIS data set is particularly useful for the analysis. These are:

(i) It identifies entry behavior each year, allowing us to build a panel of entry data that we use to control for spatial fixed effects.

(ii) It provides spatial detail on entry decisions (necessary for discussion of policies to promote entry into lagging regions).

(iii) It describes firm family structure (i.e., identifies parent or headquarters, which we find to be a particularly important determinant of entry).

To model spatial entry decisions, we had to select an appropriate geographic unit. Using municipalities creates several problems: (i) there are a large number of municipalities (5,506 in the year 2000), which would significantly increase the computational burden in estimating the location decision model; (ii) many municipalities are very small (i.e., with fewer than 5,000 inhabitants) and/or in rural areas with very few establishments in the formal sector; (iii) because of the continuous creation of new municipalities in Brazil, it is necessary to coordinate different municipality maps across the

\footnotetext{
${ }^{2}$ Refer to Table 5 for a list of the industries included in the analysis.

${ }^{3}$ The establishment with digits " 0001 " in positions 9 to 12 is the initial headquarters of the company. However, should the headquarters be transferred to another municipality and the previous establishment be maintained, the new headquarters may receive a four-digit sequence different from " 0001 " while the previous establishment retains the "0001" four-digit code, even though it is not the headquarters anymore. On the other hand, it may happen that if the headquarters moves to another municipality, it will keep the same CNPJ, and in this case, we still have the headquarter with the "0001" code. Even though we cannot identify these
} 
years of study; and (iv) entry into municipalities within the same urban area is likely to be highly correlated. Given these problems, we decided instead to use the concept of "urban agglomerations,” defined in a comprehensive urban study developed by IPEA, IBGE and Unicamp (2002), and used by Da Mata, Deichmann, Henderson, Lall and Wang (2005a and 2005b).

Even though we had RAIS micro data available from 1986 to 2003, we found the data from 1993 to 2001 to be more reliable and therefore use only these years for the analysis. For each year, we identified new establishments with at least 10 employees, and recorded the urban agglomeration in which they entered. If the entering establishment belonged to a multi-establishment firm, we also identified the agglomeration of the parent.

As can be noted from Table 1, most parent establishments are located in the Southeast (58.15\% in 1993). Note, however, that the percentage of entering parent firms over the period 1993-2001 (i.e., the CF years) falls to 42.7\% in the Southeast, but rises to 21.01\% in the Northeast (from $12.49 \%$ of the parents in 1993). Thus, considering only the spatial distribution of parents (which are footloose by definition), there is some evidence that the CF's were effective. There is also evidence in this table, however, that if branches are closely tied to parents, the CF's have a lot to overcome in vertically integrated industries, given the initial distribution of parent firms in 1993.

How empirically relevant is the "pull" of the parent firm? The answer depends upon the sector being considered. Table 2 shows percentage of entrants over years 19932001 that have headquarters. We would expect proximity to the parent to be particularly important for Metallurgy, Communcations and Electronics, Transportation, Chemicals, and importance of the "0001" headquarters location, which suggests the validity of our assumptions. 
Shoes. Table 2 also shows the average distance branch plants locate from headquarters (conditional on having a headquarters). These numbers are very small, providing further evidence that the pull of the parent is significant.

In addition to the role of firm family structure, we also explore the role played by a variety of other urban agglomeration attributes (e.g., indicators of economic development, infrastructure, education, and inter/intra-industry spillovers). ${ }^{4}$ Table 3 summarizes these attributes by region, and Table 4 demonstrates that many of these variables are highly correlated with one another. This will make it difficult to infer their separate causal roles.

\section{An Estimation Strategy to Examine the Impact of Regional Subsidies}

Our estimation strategy is designed to answer the following questions: (i) were the CF's effective in inducing firms to locate new establishments in Brazil's lagging regions, (ii) what role does the spatial distribution of a multi-unit firm play in the location decision, and (iii) what local attributes are important factors in firms' location decisions. In answering these questions, we face a number of challenges. First among these is separating the role of idiosyncratic firm characteristics from those of local attributes and CF allocations. In particular, in deciding where to place a new branch plant, a multi-unit firm may take into account proximity to the firm's headquarters. The location of each firm's headquarters will be unique, and it is unclear a priori in what direction ignoring this factor would bias our conclusions. ${ }^{5}$

\footnotetext{
${ }^{4}$ For further description of the variables used, refer to Da Mata, Deichmann, Henderson, Lall and Wang (2005a and 2005b).

${ }^{5}$ Given that most firms' headquarters were located in the Southeast, our expectation is that failing to account for the pull of parent firms would lead us to overstate the quality of the Southeast region for entry by branch plants. Because this region did not receive any CF support, this would likely have the effect of biasing downward the estimated impact of the CF's.
} 
Second, we must separate the role of the CF subsidies from that of unobserved local attributes. The CF is a subsidy to promote entry into lagging regions. Regions with high subsidies are therefore likely to be unattractive for entry in a variety of other dimensions. Data to control parametrically for these other factors are incomplete, creating a problem of (negatively) correlated unobservables. We exploit useful features of the RAIS data set to control for this problem with agglomeration fixed effects.

Finally, in determining the role played by other factors in the entry decision (e.g., classical determinants like transportation cost and market size, along with agglomeration effects and other forms of local spillovers), we are confronted with problems of severe multicollinearity. In Brazil, development (as measured by the IDH) is highly correlated with measures of education, infrastructure (e.g., sewage, electrification), and even transport accessibility. This will limit our ability to deduce the separate causal role of many of these factors.

In dealing with these complications, we undertake a multi-stage estimation procedure. The following sub-sections describe each of these stages. The next section provides a discussion of the results.

\section{Stage \#1: Maximum Likelihood Entry Model}

In the first stage, we recover non-parametric estimates of each agglomeration's overall attractiveness for entry (separately for each sector), taking into account the possibility that a firm might consider the proximity of the new site to its headquarters. 
Ceteris paribus, we should expect firms to dislike locating their plants long distances from the parent. The magnitude (and even sign) of this effect, however, may differ by sector.

We model the payoff to an entering plant $i$ (part of firm $k$ in industry $m$ ) from locating in agglomeration $j$ in year $t$ as: ${ }^{6}$

$$
\Pi_{i, j, k, t}^{m}=\delta_{j, t}^{m}+\beta_{t}^{m} D_{i, j, k, t}+\eta_{i, j, k, t}
$$

where

$$
\begin{aligned}
\delta_{j, t}^{m}= & \begin{array}{l}
\text { fixed effect capturing all features of agglomeration } j \text { in period } t \text {, as } \\
\text { perceived by a potential entrant in industry } m^{7}
\end{array} \\
D_{i, j, k, t}= & \begin{array}{l}
\text { distance }(\mathrm{km}) \text { to the parent of plant } i \text { from location } j \text { in year } t(=0 \\
\text { if no parent) }
\end{array} \\
\eta_{i, j, k, t}= & \begin{array}{l}
\text { unobserved idiosyncratic features of location } j \text { in year } t \text { specific to } \\
\text { plant } i \text { from firm } k
\end{array}
\end{aligned}
$$

We take the set of all entering firms in each year as given and model their entry decision over the set of all locations. ${ }^{8}$ Assuming $\eta_{i, j, k}$ is distributed i.i.d. Type I Extreme Value, the probability that plant $i$ enters agglomeration $j$ in year $t$ is given by:

\footnotetext{
${ }^{6}$ While we estimate separate payoff function parameters for each sector, we do not differentiate between firms of different sizes in the current analysis. Doing so will be important for future work, as previous research has found that larger firms may be more responsive to local variables in a model of spatial entry, either because of economies of scale in spatial search or because smaller firms may be more tied to the home of the entrepreneur. (Levinson 1996)

${ }^{7}$ At this stage of the model, $\delta_{j, t}^{m}$ can be assumed to control for a wide variety of local attributes including (but not limited to) indicators of development (e.g., sewage, electrification, piped water), measures of transportation accessibility (e.g., cost of transporting freight to Sao Paulo), the education and income of the local population (e.g., average education of the population over age 25, illiteracy rate), market size (i.e., population, income), and spillovers with other firms (both within and across sectors).
} 
(2) $\quad P_{i, j, k, t}^{m}=\frac{E X P\left\{\delta_{j, t}^{m}+\beta_{t}^{m} D_{i, j, k, t}\right\}}{\sum_{l=1}^{J} \operatorname{EXP}\left\{\delta_{l, t}^{m}+\beta_{t}^{m} D_{i, l, k, t}\right\}}$

The likelihood of the observed data (defined separately for each industry $m$ and year $t$ ) is thus given by:

$$
L_{t}^{m}\left(\bar{D}_{t}^{m} ; \beta_{t}^{m}, \bar{\delta}_{t}^{m}\right)=\prod_{i \in m} \prod_{j=1}^{J}\left[P_{i, j, k, t}^{m}\right]^{\lambda_{i, j, t}}
$$

where $\lambda_{i, j, t}=1$ if plant $i$ sites in agglomeration $j$ in year $t(=0$ otherwise). Maximizing this expression yields estimates of $\beta_{t}^{m}$ and $\bar{\delta}_{t}{ }^{m} \cdot{ }^{9}$

A practical difficulty arises in this stage of the estimation. In particular, some urban agglomerations may not be entered by any plants in an industry in a particular year. The data, therefore, reveal only that these locations are inherently undesirable, but do not indicate just how undesirable. The fixed effects $\delta_{j, t}^{m}$ are not identified for these locations. This is fundamentally a censored data problem. Unlike traditional approaches to this

\footnotetext{
${ }^{8}$ More specifically, our estimation algorithm uses only the information contained in the share of new entrants choosing to locate in each agglomeration, and does not use the total number of new entrants for identification.

${ }^{9}$ Explicitly maximizing the likelihood function in (3) over the full vector of fixed effects $\bar{\delta}_{t}^{m}$ may prove computationally difficult. We therefore employ the contraction mapping proposed by Berry (1994) and used in Berry, Levinsohn, and Pakes (1995) to avoid this problem. Practically, we integrate over entrants $i$ in equation (2), yielding expressions for the predicted share of plants in each sector choosing to locate in each agglomeration in each year. Given a guess for the value of $\beta_{t}^{m}$, these expressions constitute a contraction mapping in the vector of $\delta_{j, t}^{m}$ 's. We use this mapping to find the unique set of $\delta_{j, t}^{m}$ 's that make the shares predicted by the model equal the actual shares within some acceptable level of tolerance. The likelihood function is calculated based on these $\delta_{j, t}^{m}{ }^{\prime} s$. The parameter $\beta_{t}^{m}$ is updated in such a way as to increase that
} 
problem (which rely on strong distributional assumptions), we solve it by ascribing a very small minimum artificial number of entrants (e.g., $10^{-6}$ ) to each agglomeration - a numerical "patch". Depending upon how small of a patch is assumed, the estimated values of $\delta_{j, t}^{m}$ for each un-entered agglomeration can be arbitrarily negative. Timmins and Murdock (2005) demonstrate that, as the patch size becomes increasingly small, the estimated values of $\delta_{j, t}^{m}$ for those agglomerations that are entered converge to stable values. As long as a majority of agglomerations are entered by each sector, median regression used to recover the determinants of $\delta_{j, t}^{m}$ will be unaffected by the artificially assumed number of entrants in un-entered agglomerations. ${ }^{10}$

\section{Stage \#2: Median Regression and the Role of the Constitutional Funds}

In order to evaluate the role of the CF's in promoting entry, we use median regression on the panel of data (defined over $\mathrm{J}=265$ agglomerations and $\mathrm{T}=9$ years) for each industry. ${ }^{11}$

$$
\delta_{j, t}^{m}=\gamma^{m}+\overline{Y E A R^{\prime}}{ }_{t} \theta^{m}+\overline{A G G^{\prime}}{ }_{j} \phi^{m}+\psi^{m} C F_{j, t}+u_{j, t}^{m}
$$

where

likelihood value, and the contraction mapping is repeated in order to recover new $\delta_{j, t}^{m}$ ' $s$. The procedure is complete when the likelihood function is maximized.

${ }^{10}$ See Koenker and Basset (1978) and Koenker and Hallock (2001) for comprehensive discussions of median regression.

${ }^{11}$ Note that estimating this equation via median regression requires explicit estimation of all fixed effects differencing the data is not equivalent to fixed effect estimation in the median regression context. 


$$
\begin{aligned}
& \overline{Y E A R}_{t}= \begin{array}{l}
\text { vector of dummy variables indicating year }=1994, \ldots, 2001 \\
\\
(1993 \text { excluded) }
\end{array} \\
& \overline{A G G}_{t}=\begin{array}{l}
\text { vector of dummy variables indicating agglomeration }=2, \ldots, 265 \\
\text { (agglomeration } 1 \text { excluded) }
\end{array} \\
& C F_{j, t}=\begin{array}{l}
\text { average CF allocation per employee in year } t \text { in the state } \\
\text { containing agglomeration } j^{I 2}
\end{array} \\
& u_{j, t}^{m}=\quad \begin{array}{l}
\text { unobservable determinant of entry quality in agglomeration } j \text { for } \\
\text { firms in sector } m \text { in year } t
\end{array}
\end{aligned}
$$

The vector of year dummies is included to account for the fact that an arbitrary normalization underlies the vector of $\bar{\delta}_{t}^{m}$ in each year $t$ (in particular, these fixed effects have no natural scale, so we normalize them so that their average values equal zero in each year for each industry).

The vector of agglomeration dummies plays an especially important role in this regression. In particular, CF's are allocated in a remedial fashion (i.e., with more funds being allocated toward locations that are less attractive for entry). ${ }^{13}$ A regression of $\delta_{j, t}^{m}$ on only year dummies and CF allocations therefore suffers from an omitted variable bias in particular, a bias towards finding that the CF's had no impact (or even an adverse

\footnotetext{
${ }^{12}$ In particular, we take the ex post contracted allocation of CF's in each state in each year and divide by the number of entering plants. This controls for the fact that attractive states experiencing more entry will, by definition, receive more CF allocations. The size of the entering firms will also have an effect on the overall allocation each state receives (bigger firms will receive larger subsidies than small firms). We therefore divide by the average firm size (i.e., employees per firm) amongst entrants in each state in each year. This converts our measure of CF's into the average contracted allocation per employee in each state, which we treat as an exogenous measure of the state's attractiveness in terms of the CF. Note one remaining potential source of bias - firms with better credit ratings will receive higher CF subsidies (conditional upon size). If firms with better credit ratings disproportionately locate in sites with desirable unobservables, the error in our CF measure will be correlated with those unobservables, biasing our results towards finding positive effects of the CF's. We demonstrate below, however, that this potential source of bias is not a concern in interpreting our results.

${ }^{13}$ This is apparent when one considers that the Funds were only made available to firms entering in the Northeast, North, and Center-West regions, in order to help draw them away from the more affluent South and Southeast.
} 
impact) on entry behavior. With only cross-sectional data, one would be forced to deal with this fact by including as many agglomeration attributes in the model as possible. While such data exist, they will necessarily be incomplete. With our panel data (obtained by using annual entry behavior observed in the RAIS), we are able to control nonparametrically for any features of each agglomeration that do not change over time. This takes care of the most important differences between agglomerations, and leaves us with the variation in CF allocations over time with which to identify their impact.

\section{Stage \#3: Decomposing Agglomeration Fixed Effects}

In the final stage of our estimation procedure, we explore the role of determinants of entry behavior besides the CF's. At the end of Stage \#2, we are left with the vector of agglomeration-and-industry fixed effects, $\bar{\phi}^{m}$. These fixed effects describe the attractiveness of each agglomeration for each industry $m$, averaged over the period 19932001, after having controlled for headquarter locations, time effects, and CF allocations. Ideally, we could take these fixed effects and regress them on a vector of city attributes; e.g., $X_{j}=\{\mathrm{IDH}$, education, infrastructure, employment in sector $m$ (i.e., agglomeration effects), employment in other sectors (i.e., spillover effects)\}. In practice, this is complicated by two factors. First, many of these attributes are highly correlated with one another (see Table 4). Results of such a procedure are therefore highly sensitive to the exact specification assumed. Second, it is likely that some of these attributes are actually determined by the entry behavior of firms, and are therefore endogenous to the regression. This is especially true of the aggregated entry decisions of other firms. In this case, a simple decomposition like that described above would yield biased estimates. 
Even without determining the causal effect of agglomeration attributes on $\bar{\phi}^{m}$, we can learn something about which attributes are more closely associated with entry. In particular, for each industry, we divide agglomerations into two groups according to the median value of $\phi_{j}^{m}-$ "l” = low (i.e., below the median) and " $h$ " = high (i.e., above the median):

$$
\Omega_{l}^{m}=\left\{j: \phi_{j}^{m} \leq \operatorname{Median}\left[\phi_{j}^{m}\right]\right\} \quad \Omega_{h}^{m}=\left\{j: \phi_{j}^{m}>\operatorname{Median}\left[\phi_{j}^{m}\right]\right\}
$$

Agglomerations in the group labeled $\Omega_{l}^{m}$ are generally less attractive destinations for new entrants in sector $m$ (controlling for CF allocations, other time-varying local unobservables, and the spatial distribution of firm headquarters). We then take the mean of each agglomeration attribute within each group, and look for significant differences. While not evidence of a causal effect, a significant difference does imply a tendency for certain kinds of firms to gravitate toward destinations with certain kinds of attributes. This exercise motivates a more structural analysis of the determinants of entry decisions in later work. 


\section{Results}

\section{The Role of Parent Location in Entry}

Table 5 reports the results of our first stage estimates of $\beta_{t}^{m}$ for each of eighteen sectors. ${ }^{14}$ In every instance, firms exhibit a statistically significant preference for siting their new plants close to their headquarters. In recovering these effects, Stage \#1 of our estimation strategy non-parametrically controls for everything about agglomerations that varies by sector and year and that might be a determinant of firm entry. This should control for the most important confounding factors (i.e., for any factor that makes it attractive to put any firm from a particular sector - headquarters or otherwise - in the agglomeration). It cannot distinguish, however, between distance effects and the effect of idiosyncratic unobservables. ${ }^{15}$

While providing evidence of statistical significance, the parameter estimates in Table 5 do not, however, allow us to judge the economic significance of the "pull" of the firm headquarters in plant location decisions. In particular, in each of the maximum likelihood procedures underlying the estimates reported in Table 5, there is a vector of fixed effects normalized so that their average value equals zero. This normalization is arbitrary, and makes direct comparison of parameter estimates across years or industries impossible. More can be learned about the way in which these firm headquarters influence entry behavior by way of simulation. In particular, it is possible to simulate how entry patterns would have differed by sector and region if firms did not care about proximity to

\footnotetext{
14 Estimates of $\delta_{j, t}^{m}$ are not reported for the sake of brevity, but will be used in the following sub-section to explore the role of the CF's.

15 For example, the model would interpret a case in which an entrepreneur has a strong preference for a particular agglomeration and locates all of his plants and headquarters there as a distaste for locating branch plants far from the headquarters.
} 
headquarters. Assuming that the values of $\delta_{j, t}^{m}$ are not affected by this counterfactual assumption, ${ }^{16}$ we simply "turn off" the distance-to-parent coefficient in the entry model, and simulate new entry patterns in each year. Table 6 reports the percent change in the distribution of entry (i.e., between actual and predicted under this counterfactual assumption), across regions and aggregated over the years 1993-2001. The biggest differences are seen in the North (i.e., where relatively few headquarters were in place in any sector, but which sees the biggest gains when distance-to-parent effects are taken out) and in the Southeast (i.e., the home to the majority of headquarters, which sees the largest drop in entry). The Northeast, Center-West, and South see mixed effects that vary by sector, although the general trend is for entry to increase in these sectors when we make all plants "footloose".

\section{The Effectiveness of the Constitutional Funds}

Table 7 describes our decomposition of the fixed effects, $\delta_{j, t}^{m}$. Columns describe the results of median regressions that (i) exclude agglomeration fixed effects, using only year fixed effects and annual CF contracts per employee, (ii) use year fixed effects and annual CF contracts per employee along with a collection of covariates describing observable agglomeration attributes, ${ }^{17}$ and (iii) use year fixed effects, agglomeration fixed effects, and annual CF allocations. In the table, we report only the coefficient on the CF variable. Without any controls for agglomeration heterogeneity in column (i), we find

\footnotetext{
${ }^{16}$ If entry by firms in one year makes a region more attractive for entry by firms in the same and other sectors in later years, this assumption implies that we will understate the impact of removing parent effects on lagging regions.

${ }^{17}$ In particular, we use the average of the 1990 and 2000 Human Development Indices, populations, and average years of education of those over the age of 25, along with the 1995 transportation cost to Sao Paulo. 1995.
} 
significant (both economically and statistically) negative effects of the CF on entry. This result corresponds to that found in previous work (Ferreira 2004) and likely reflects the fact that the CF's are allocated in a remedial fashion. Including covariates in column (ii) to control for local attributes does little to change these results.

Time-invariant forms of heterogeneity are non-parametrically controlled for by the introduction of agglomeration fixed effects. These are included in the specification described in column (iii), where we find significant positive effects of the CF's on entry for five out of the eleven manufacturing industries, and positive but insignificant effects for all but paper and publishing and metallurgy (where effects are negative and insignificant).

While the fixed effects succeed in alleviating the downward bias in the CF parameters that is evident in columns (i) and (ii), keep in mind that there still may be some remaining downward bias caused by time varying forms of local heterogeneity that are negatively correlated with CF allocations. We are less concerned with the potential for bias introduced by the mis-measurement of CF allocations resulting from the non-random siting of plants according to their credit rating (see footnote 12). In particular, we would expect that firms with more talented entrepreneurs would have better credit ratings and that these entrepreneurs would be more likely to site plants in locations with desirable unobservable attributes. This would tend to bias the coefficient on CF in our median regressions upward. This source of bias should go down, however, when we introduce agglomeration fixed effects to account for time-invariant forms of unobserved heterogeneity. It is precisely when we introduce these fixed effects, however, that the sign of most of our CF effects increases dramatically, switching from negative to positive. 
Clearly, if there had been an upward bias in the absence of these fixed effects, it was not very big and was swamped by the bias introduced by the correlation between CF and undesirable unobservable local attributes.

Of the non-manufacturing sectors, only retail, transportation and communication, and hotel and food services show positive effects from the CF's. Non-manufacturing sectors are generally not covered by the CF's, so we should not expect to see the positive effect here that we saw in the case of most manufacturing industries. Entry in the retail sector, however, may quickly follow manufacturing entry and, hence, exhibit a positive correlation with CF. In addition, the CF's have been used to promote tourism related activities, which may influence firm entry in the hotel and food services and transportation and communication sectors (Ferreira 2004).

In general, our results suggest that the CF's, by themselves, have stimulated entry in the lagging regions of Brazil - particularly in the case of machinery, transportation equipment, wood and furniture, textiles, and food and beverages. In order to put the role of the CF's in perspective, consider the reduction in distance-to-parent that would be required to compensate for taking them away - i.e., a compensating variation (CV) in distance-to-parent. These are described in Table 8. We find that distance to parent would have to fall by between 5 and $26 \%$ to compensate for the loss of the CF's, holding firm payoffs constant. This CV is smaller for plants in the Northeast (where CF allocations per employee are smaller on average), and for industries more sensitive to distance-to-parent (e.g., Food, Beverages, and Alcohol). 


\section{Other Determinants of Entry Behavior}

Tables 9 (a)-(i) report the results of our exploratory analysis of the other possible determinants of plant entry. These results are based on decomposing the agglomerationindustry fixed effects, which we get from Stage \#2. As we discuss in Section 4, these decompositions do not establish causality in terms of other factors that make certain regions more attractive for some industries, but still help us identify attributes which are closely associated with firm entry.

Firm entry in all manufacturing sectors and most non-manufacturing sectors is higher in agglomerations with lower transport costs to Sao Paulo. Similarly, agglomerations with better development indicators as measured by the IDH, education attainment, and availability of public services (such as garbage collection and piped water availability) have higher firm entry in most sectors.

One would also expect that new firms would locate in areas which have higher representation of firms in their own or inter related industries. However, the evidence to

support the importance of agglomeration economies is limited. ${ }^{18}$ Only in the machinery and textiles industries do we find that a higher presence of firms in the same industry is associated with higher firm entry between 1993 and 2001. 


\section{Conclusions}

We learn two things from this analysis. First, (contrary to previous work) we find that the CF allocations have, in fact, been successful in inducing entry into lagging regions, conditioning on the location of firms' headquarters. This result however, can be easily lost among the confounding effects of local unobservables that are negatively correlated with CF allocations. It is hard to capture these determinants of entry with available data describing agglomeration attributes, but without properly accounting for these factors, there is a bias toward finding a negative effect of the CF's. The RAIS data, which describe spatial entry behavior on an annual basis, provide a unique opportunity to overcome this problem non-parametrically.

Second, we learn that, while the CF's were successful, headquarter proximity is a significant determinant of entry behavior (conditional upon having a parent) that works to offset this success. Simply "turning-off" the effect of parent firm location significantly raises overall entry into lagging regions. These effects are, moreover, likely a lower bound on the effect of removing the pull of firm headquarters if we believe that there are positive spillovers between entrants.

The conclusions of this paper for policy-makers are, unfortunately, limited. While we find that the CF's were successful in inducing firms to locate in Brazil's lagging regions (and that the CF's may yield more "bang for the buck" if they are used to induce entry by firms' headquarters into those regions), we are unable to determine whether the CF's were good policy or not. In further research, we plan to move from the limited question of "do subsidies affect firm location decisions" to the more policy-relevant

\footnotetext{
${ }^{18}$ These findings are consistent with Lall, Funderburg, and Yepes (2005) who examine the effect of transport costs and agglomeration economies on manufacturing wages in Brazil. They find that while wages are higher
} 
question of "are these subsidies welfare enhancing”. In answering that question, it will be crucial to determine (i) whether the CF's induced new entry into lagging regions or simply re-allocated entry away from the South and Southeast regions, and (ii) what was the productivity effect on re-located firms. ${ }^{19}$ Answering these questions was not possible with the data used in this paper, but may require new efforts in collecting survey data from entrepreneurs about what motivated their entry decisions, and about their inputs and outputs conditional upon those decisions.

\footnotetext{
in regions with improvements in transport networks, agglomeration economies have very modest effects.

${ }^{19}$ In addition to informing us on the value of the CF's, this latter point will speak to the question of whether or not there is generally a tradeoff between regional distribution objectives and national economic growth. This question has broad implications beyond the current study.
} 


\section{References}

Azzoni, C. R., N. Menezes-Filho, T. A. de Menezes and R. Silveira-Neto (2002), “Geography and Income Convergence among Brazilian States”, Mimeo.

Baer, W. (1995). The Brazilian Economy: Growth and Development. 4th ed. Westport: Praeger.

Berry, S. (1994). “Estimating Discrete Choice Models of Product Differentiation.” RAND Journal of Economics. 25:242-262.

Berry, S., J. Levinson, and A. Pakes. (1995). “Automobile Prices in Market Equilibrium.” Econometrica. 63:841-890.

Da Mata, D., U. Deichmann, J.V. Henderson, S.V Lall and H. Wang. (2005a). Determinants of City Growth in Brazil. IPEA Discussion Paper No. 1112. Brasília. 2005.

Da Mata, D., U. Deichmann, J.V. Henderson, S.V Lall and H. Wang. (2005b). Examining the Growth Patterns of Brazilian Cities. IPEA Discussion Paper No. 1113. Brasília. 2005.

Ellery Jr. R. and Ferreira, P.C. (1996) “Crescimento Economico e Convergencia entre a Renda dos Estados Brasileiros.” Revista de Econometria. 16(1):83-104.

Ferreira, A.H.B. (2000) "Convergence in Brazil: Recent Trends and Long Run Prospects.” Applied Economics. 32: 479-489.

Ferreira, P. C. (2004) “Regional Policy in Brazil: A Review.” Mimeo.

Goldsmith, W. and R. Wilson. (1991). Poverty and Distorted Industrialization in the Northeast, World Development. 19(5):435-55.

IPEA, IBGE, and UNICAMP (2002). Configuração Atual e Tendências da Rede Urbana, Série Configuração Atual e Tendências da Rede Urbana, Instituto de Pesquisa Econômica Aplicada, Instituto Brasileiro de Geografia e Estatística, Universidade Estadual de Campinas, Brasília.

Jalan, J. and M. Ravallion. (1997) “Spatial poverty traps?” Policy Research Working Paper

No. 1862, Development Research Group, World Bank, Washington, D.C.

Koenker, R. and G. Bassett (1978). “Regression Quantiles.” Econometrica. 46(1):33-50.

Koenker, R. and K. Hallock (2001). “Quantile Regression.” Journal of Economic Perspectives. 15(4):143-156. 
Lall, S. V. and Z. Shalizi (2003) “Location and growth in the Brazilian Northeast.” Journal of Regional Science. 43(4):1-19.

Lall, S.V., R. Funderburg, and T. Yepes (2005). Location, Concentration, and Performance of Economic Activity in Brazil. Development Research Group, The World Bank.

Levinson, A. (1996). “Environmental regulations and manufacturers' location choices: Evidence from the Census of Manufactures." Journal of Public Economics. 62:529.

Maia Gomes (2002). “Regional Development Strategies in Brazil.” Mimeo.

Markusen, A. (1994). Interaction Between Regional and Industrial Policies: Evidence from Four Countries. Proceedings of the World Bank Annual Conference on Development Economics, Washington, D.C.

Secretaria da Receita Federal (2003) “Demonstrativo dos Benefícios Tributários”, agosto, Brasília/DF.

Timmins, C. and J. Murdock. (2005). "A Revealed Preference Approach to the Measurement of Congestion in Travel Cost Models.” Mimeo, Duke University Department of Economics. Available http://www.econ.duke.edu/ timmins/fishing_new.doc

World Bank. (1987). Brazil: Industrial Development Issues of the Northeast. World Bank Economic and Sector Report. Washington, D.C.

World Bank. (1998). Public Expenditures for Poverty Alleviation in Northeast Brazil: Promoting Growth and Improving Services. World Bank Report 18700-BR.

World Bank. (2005). Brazil Regional Economic Development - (Some) Lessons from Experience. World Bank Report August. 
Table 1 - Spatial distribution of Firm Headquarters in 1993

\begin{tabular}{|l|c|c|c|c|}
\hline \multirow{2}{*}{ State/Region } & \multicolumn{2}{|c|}{ Distribution of Parent Firms (1993) } & \multicolumn{2}{c|}{$\begin{array}{c}\text { Entry by Parent Firms } \\
(1993-2001)\end{array}$} \\
\hline & Firm Count & $\%$ & Firm Count & $\%$ \\
\hline Rondonia & 157 & 0.71 & 195 & 1.33 \\
\hline Acre & 49 & 0.22 & 33 & 0.23 \\
\hline Amazons & 211 & 0.95 & 194 & 1.33 \\
\hline Roraima & 24 & 0.11 & 39 & 0.27 \\
\hline Para & 304 & 1.38 & 248 & 1.70 \\
\hline Amapa & 47 & 0.21 & 42 & 0.29 \\
\hline Tocantins & 124 & 0.56 & 41 & 0.28 \\
\hline North & 916 & 4.14 & 792 & 5.42 \\
\hline Maranhao & 172 & 0.78 & 224 & 1.53 \\
\hline Piaui & 145 & 0.66 & 122 & 0.83 \\
\hline Ceara & 494 & 2.23 & 509 & 3.48 \\
\hline Rio Grande do Norte & 177 & 0.80 & 218 & 1.49 \\
\hline Paraiba & 136 & 0.62 & 219 & 1.50 \\
\hline Pernambuco & 612 & 2.77 & 609 & 4.17 \\
\hline Alagoas & 135 & 0.61 & 153 & 1.05 \\
\hline Sergipe & 127 & 0.57 & 122 & 0.83 \\
\hline Bahia & 763 & 3.45 & 895 & 6.12 \\
\hline Northeast & 2761 & 12.49 & 3071 & 21.01 \\
\hline Minas Gerais & 2064 & 9.34 & 1339 & 9.16 \\
\hline Espirito Santo & 472 & 2.13 & 301 & 2.06 \\
\hline Rio de Janeiro & 2673 & 12.09 & 1101 & .53 \\
\hline Sao Paulo & 7648 & 34.59 & 3499 & 23.94 \\
\hline Southeast & 12857 & 58.15 & 6240 & 42.70 \\
\hline Parana & 1400 & 6.33 & 1026 & 7.02 \\
\hline Santa Catarina & 957 & 4.33 & 871 & 5.96 \\
\hline Rio Grande do Sul & 1700 & 7.69 & 746 & 5.10 \\
\hline South & 4057 & 18.35 & 2643 & 18.09 \\
\hline Mato Grosso do Sul & 220 & 1.00 & 207 & 1.42 \\
\hline Mato Grosso & 325 & 1.47 & 549 & 3.76 \\
\hline Goias & 534 & 2.42 & 614 & 4.20 \\
\hline Distrito Federal & 439 & 1.99 & 498 & 3.41 \\
\hline Center-West & 1518 & 6.87 & 1868 & 12.78 \\
\hline Brazil & 22109 & 100.00 & 14614 & 100.00 \\
\hline
\end{tabular}


Table 2 - Entrant Descriptive Statistics

\% Entrants with Parent Firms and Average Distance

to Parent Firm After Entry (Conditional on Having Parent)

\begin{tabular}{|c|c|c|}
\hline IBGE Sector & $\begin{array}{l}\text { Percent Entrants with } \\
\text { Parent }\end{array}$ & $\begin{array}{l}\text { Avg. Distance to } \\
\text { Parent }(\mathrm{km})\end{array}$ \\
\hline Metallurgy & 15.15 & 48.41 \\
\hline Machinery & 1.56 & 143.50 \\
\hline Communications and Electronic Equipment & 15.81 & 38.80 \\
\hline Transportation Equipment & 16.04 & 119.83 \\
\hline Wood and Furniture & 1.59 & 80.11 \\
\hline Paper and Publishing & 2.86 & 99.18 \\
\hline Rubber, Tobacco, and Skins & 0.99 & 68.95 \\
\hline Chemicals, Pharmaceuticals, Veterinary \& Perfume Products & 13.47 & 80.08 \\
\hline Textiles & 1.24 & 67.00 \\
\hline Shoes & 14.22 & 104.07 \\
\hline Food, Beverages, and Alcohol & 0.99 & 79.07 \\
\hline Retail & 2.33 & 94.86 \\
\hline Credit Institutions, Insurance, \& Capitalization & 41.63 & 52.81 \\
\hline Real Estate & 16.71 & 123.26 \\
\hline Transportation \& Communication & 2.51 & 107.73 \\
\hline Hotel and Food & 2.65 & 56.98 \\
\hline Medical, Veterinary, and Dentistry Services & 14.40 & 29.22 \\
\hline Education & 61.63 & 134.96 \\
\hline
\end{tabular}


Table 3 - Summary Statistics

Urban Agglomeration Attributes ${ }^{20}$

\begin{tabular}{|c|c|c|c|c|c|}
\hline Number of Agglomerations & $\begin{array}{c}\text { North } \\
11\end{array}$ & $\begin{array}{c}\text { Northeast } \\
102\end{array}$ & $\begin{array}{c}\text { Southeast } \\
94\end{array}$ & $\begin{array}{c}\text { South } \\
38\end{array}$ & $\begin{array}{c}\text { Center-West } \\
20\end{array}$ \\
\hline Population (1991) & 522092.0 & 223036.7 & 508593.2 & 400874.6 & 394631.7 \\
\hline Transportation Cost to Sao Paulo (1995) & 3617.85 & 2391.48 & 460.07 & 830.49 & 1372.84 \\
\hline Human Development Index (1990) & 0.68 & 0.57 & 0.75 & 0.74 & 0.70 \\
\hline Average Years of Education, 25 years and Older (1991) & 4.51 & 3.09 & 5.38 & 5.30 & 4.52 \\
\hline \% Households Garbage Collection (1991) & 50.86 & 56.05 & 85.47 & 84.17 & 67.13 \\
\hline \% Households Electric Lighting (1991) & 78.86 & 72.50 & 97.20 & 94.49 & 83.67 \\
\hline \% Households Piped Water (1991) & 49.48 & 46.82 & 92.31 & 88.50 & 69.31 \\
\hline Theil Index (1991) & 0.60 & 0.57 & 0.52 & 0.52 & 0.57 \\
\hline Employment: Mining & 1158.69 & 315.73 & 715.88 & 562.09 & 756.73 \\
\hline Employment: Agriculture & 32477.42 & 13151.70 & 7436.58 & 23281.34 & 24748.08 \\
\hline Employment: Commerce & 29604.55 & 12154.11 & 31590.26 & 26244.20 & 24762.45 \\
\hline Employment: Construction & 11823.70 & 5502.84 & 16752.00 & 12790.92 & 12553.95 \\
\hline Employment: Finance & 1547.63 & 829.10 & 4364.00 & 2922.67 & 2526.63 \\
\hline Employment: Fishing & 1586.76 & 513.09 & 189.65 & 404.78 & 172.75 \\
\hline Manufacturing Employment: Chemicals & 331.00 & 453.78 & 3021.86 & 880.76 & 639.02 \\
\hline Manufacturing Employment: Electrical & 3577.45 & 112.22 & 1891.81 & 1106.76 & 132.65 \\
\hline Manufacturing Employment: Food & 2490.91 & 1776.09 & 5134.47 & 5165.89 & 2538.37 \\
\hline Manufacturing Employment: Furniture & 1567.45 & 579.17 & 2009.76 & 2379.74 & 1337.46 \\
\hline Manufacturing Employment: Leather & 16.09 & 51.26 & 236.36 & 667.26 & 61.20 \\
\hline Manufacturing Employment: Machinery & 377.09 & 118.72 & 1737.57 & 1432.47 & 177.60 \\
\hline Manufacturing Employment: Metals & 1408.45 & 693.58 & 8591.06 & 4380.76 & 983.22 \\
\hline Manufacturing Employment: Paper & 145.45 & 84.42 & 941.97 & 661.24 & 41.65 \\
\hline Manufacturing Employment: Petroleum & 101.27 & 179.88 & 366.93 & 260.42 & 8.95 \\
\hline Manufacturing Employment: Plastics & 316.82 & 175.69 & 1874.13 & 1117.37 & 135.50 \\
\hline Manufacturing Employment: Printing & 630.64 & 281.65 & 2086.48 & 1055.89 & 771.85 \\
\hline Manufacturing Employment: Textiles & 555.64 & 1444.08 & 6751.52 & 4325.50 & 1190.29 \\
\hline Manufacturing Employment: Tobacco & 50.09 & 56.11 & 82.01 & 414.16 & 3.10 \\
\hline Manufacturing Employment: Transportation & 1278.64 & 210.52 & 3598.91 & 1493.45 & 446.65 \\
\hline Manufacturing Employment: Wood & 3631.82 & 470.56 & 795.14 & 1856.05 & 1940.73 \\
\hline
\end{tabular}

\footnotetext{
${ }^{20}$ Manufacturing employment measured in 1991. All other employments are the average of 1980 and 2000 values.
} 
Table 4 - Correlations Between Agglomeration Attributes

\begin{tabular}{|c|c|c|c|c|c|c|c|}
\hline & Population & $\begin{array}{c}\text { Transportation } \\
\text { Cost }\end{array}$ & $\begin{array}{l}\text { Human } \\
\text { Development } \\
\text { Index }\end{array}$ & $\begin{array}{c}\text { Avg } \\
\text { Education } \\
(>25 \text { Years) }\end{array}$ & $\%$ Garbage & $\begin{array}{l}\text { \% Electric } \\
\text { Lighting }\end{array}$ & $\begin{array}{c}\% \text { Piped } \\
\text { Water }\end{array}$ \\
\hline Population & 1.0000 & & & & & & \\
\hline Transportation Cost & -0.0831 & 1.0000 & & & & & \\
\hline Human Development Index & 0.1974 & -0.7112 & 1.0000 & & & & \\
\hline Avg Education (> 25 Years) & 0.2634 & -0.6114 & 0.9477 & 1.0000 & & & \\
\hline$\%$ Garbage & 0.1278 & -0.6626 & 0.7423 & 0.7086 & 1.0000 & & \\
\hline \% Electric Lighting & 0.1514 & -0.6064 & 0.8434 & 0.8631 & 0.7693 & 1.0000 & \\
\hline \% Piped Water & 0.1438 & -0.7763 & 0.9159 & 0.8879 & 0.8377 & 0.9074 & 1.0000 \\
\hline
\end{tabular}


Table 5 (a) - First Stage Parameter Estimates and Standard Errors Disutility of Distance from Firm Headquarters

\begin{tabular}{|c|c|c|c|c|c|c|c|c|c|}
\hline & $\begin{array}{l}\text { Metallurgic } \\
\text { Industries }\end{array}$ & $\begin{array}{l}\text { Mechanic } \\
\text { Industries }\end{array}$ & $\begin{array}{l}\text { Communication } \\
\text { \& Electric } \\
\text { Equipments }\end{array}$ & $\begin{array}{l}\text { Transportation } \\
\text { Equipments } \\
\text { Industries }\end{array}$ & $\begin{array}{l}\text { Wood \& } \\
\text { Furniture } \\
\text { Industries }\end{array}$ & $\begin{array}{l}\text { Paper \& } \\
\text { Publishing } \\
\text { Industries }\end{array}$ & $\begin{array}{l}\text { Rubber, } \\
\text { Tobacco, \& } \\
\text { Skins } \\
\text { Industries }\end{array}$ & $\begin{array}{c}\text { Chemical, } \\
\text { Pharmaceutical, } \\
\text { Veterinarians, } \\
\text { Perfumes, \& } \\
\text { Others } \\
\end{array}$ & Textiles \\
\hline \multirow[t]{2}{*}{1993} & -4.63335 & -1.022509 & -3.516901 & -4.11691 & -0.003287 & -0.744992 & -1.529242 & -2.251017 & -3.63653 \\
\hline & 0.061 & 0.091 & 0.586 & 0.249 & 0.156 & 0.242 & 0.252 & 0.366 & 0.351 \\
\hline \multirow[t]{2}{*}{1994} & -4.776536 & -1.026642 & -2.267564 & -2.065258 & -2.361189 & -2.319109 & -2.237593 & -1.247121 & -2.6326 \\
\hline & 0.055 & 0.098 & 0.302 & 0.097 & 0.244 & 0.359 & 0.498 & 0.221 & 0.248 \\
\hline \multirow[t]{2}{*}{1995} & -4.19655 & -1.312279 & -7.136356 & -2.911339 & -2.316447 & -1.747716 & -1.770898 & -0.5976185 & -2.77249 \\
\hline & 0.047 & 0.101 & 0.853 & 0.104 & 0.262 & 0.379 & 0.522 & 0.189 & 0.256 \\
\hline \multirow[t]{2}{*}{1996} & -4.379192 & -1.550118 & -0.9575031 & -1.989933 & -2.2154 & -1.124324 & -1.67246 & -1.791051 & $-3.7817 \varepsilon$ \\
\hline & 0.044 & 0.092 & 0.202 & 0.092 & 0.25 & 0.532 & 0.296 & 0.272 & 0.258 \\
\hline \multirow[t]{2}{*}{1997} & -4.660394 & -1.374413 & -2.661697 & -2.125658 & -2.734079 & -1.923401 & -1.569216 & -2.543844 & -2.03109 \\
\hline & 0.052 & 0.105 & 0.302 & 0.085 & 0.263 & 0.358 & 0.304 & 0.321 & 0.219 \\
\hline \multirow[t]{2}{*}{1998} & -4.666001 & -0.9885217 & -2.281698 & -1.123402 & -2.105364 & -1.66395 & -0.4725547 & -0.7038555 & -3.33133 \\
\hline & 0.051 & 0.09 & 0.334 & 0.08 & 0.326 & 0.31 & 0.283 & 0.293 & 0.263 \\
\hline \multirow[t]{2}{*}{1999} & -4.443977 & -1.245524 & -3.662842 & -1.525596 & -1.7404 & -0.896037 & -0.8281909 & -0.5695767 & -2.83038 \\
\hline & 0.049 & 0.102 & 0.309 & 0.09 & 0.252 & 0.226 & 0.205 & 0.212 & 0.261 \\
\hline \multirow[t]{2}{*}{2000} & -3.780393 & -0.9067607 & -4.836069 & -1.881727 & -3.321722 & -0.495014 & -1.316868 & -1.457993 & -2.84382 \\
\hline & 0.039 & 0.092 & 0.37 & 0.095 & 0.402 & 0.255 & 0.3 & 0.252 & 0.205 \\
\hline \multirow[t]{2}{*}{2001} & -4.211293 & -1.501673 & -5.994211 & -1.51965 & -1.665818 & -0.843011 & -1.056535 & -2.138744 & -2.3295 \\
\hline & 0.047 & 0.104 & 0.652 & 0.079 & 0.252 & 0.315 & 0.218 & 0.263 & 0.219 \\
\hline
\end{tabular}


Table 5 (b) - First Stage Parameter Estimates and Standard Errors

Disutility of Distance from Firm Headquarters

\begin{tabular}{|c|c|c|c|c|c|c|c|c|c|}
\hline & $\begin{array}{c}\text { Shoes } \\
\text { Industries }\end{array}$ & $\begin{array}{c}\text { Food, } \\
\text { Beverage, } \\
\text { \& Alcoholic } \\
\text { Items } \\
\text { Industries }\end{array}$ & Retail & $\begin{array}{c}\text { Credit } \\
\text { Institutions, } \\
\text { Insurance, \& } \\
\text { Capitalization }\end{array}$ & Real Estate & $\begin{array}{c}\text { Transportation } \\
\& \\
\text { Communication } \\
\text { Industries }\end{array}$ & $\begin{array}{c}\text { Hotel, } \\
\text { Food, } \\
\text { Repair, \& } \\
\text { Publishing } \\
\text { Services }\end{array}$ & $\begin{array}{c}\text { Medical, } \\
\text { Veterinarian, \& } \\
\text { Dentistry } \\
\text { Services }\end{array}$ & $\begin{array}{c}\text { Education } \\
\text { Services }\end{array}$ \\
\hline \multirow[t]{2}{*}{1993} & -1.616734 & -3.513587 & -3.3916 & -1.61772 & -3.519285 & -1.531885 & -2.702976 & -5.121686 & -0.701798 \\
\hline & 0.178 & 0.235 & 0.296 & 0.21 & 0.263 & 0.078 & 0.083 & 0.33 & 0.079 \\
\hline \multirow[t]{2}{*}{1994} & -0.794549 & -2.402769 & -5.2069 & -1.467135 & -1.448544 & -0.8352789 & -2.776254 & -2.500844 & -0.724495 \\
\hline & 0.123 & 0.164 & 0.503 & 0.121 & 0.197 & 0.08 & 0.08 & 0.134 & 0.075 \\
\hline \multirow[t]{2}{*}{1995} & -1.367163 & -5.365632 & -2.93199 & -2.095078 & -1.546453 & -0.7119592 & -3.089777 & -2.815874 & -0.946609 \\
\hline & 0.161 & 0.257 & 0.244 & 0.183 & 0.242 & 0.06 & 0.07 & 0.096 & 0.082 \\
\hline \multirow[t]{2}{*}{1996} & -1.772667 & -6.043686 & -3.24486 & -1.497497 & -0.6497825 & -1.213721 & -3.191817 & -4.031057 & -0.276271 \\
\hline & 0.154 & 0.394 & 0.318 & 0.123 & 0.159 & 0.076 & 0.073 & 0.146 & 0.06 \\
\hline \multirow[t]{2}{*}{1997} & -1.915038 & -4.268064 & -2.64443 & -1.946985 & -2.492992 & -0.979042 & -3.344391 & -3.138312 & -0.935676 \\
\hline & 0.139 & 0.198 & 0.253 & 0.343 & 0.416 & 0.06 & 0.079 & 0.112 & 0.08 \\
\hline \multirow[t]{2}{*}{1998} & -1.022172 & -2.55246 & -2.28974 & -2.53005 & -1.577432 & -1.054577 & -3.178292 & -3.240311 & -1.002077 \\
\hline & 0.152 & 0.171 & 0.254 & 0.193 & 0.257 & 0.069 & 0.091 & 0.129 & 0.07 \\
\hline \multirow[t]{2}{*}{1999} & -2.028531 & -5.887606 & -2.42505 & -1.51752 & -0.9626081 & -1.531746 & -3.103625 & -4.144922 & -0.730447 \\
\hline & 0.164 & 0.423 & 0.32 & 0.206 & 0.156 & 0.074 & 0.073 & 0.154 & 0.073 \\
\hline \multirow[t]{2}{*}{2000} & -1.467654 & -4.492109 & -1.76989 & -1.32374 & -1.138835 & -1.272506 & -3.2621 & -4.383683 & -0.501083 \\
\hline & 0.127 & 0.251 & 0.255 & 0.176 & 0.172 & 0.072 & 0.073 & 0.172 & 0.064 \\
\hline \multirow[t]{2}{*}{2001} & -1.249875 & -1.183984 & -2.58689 & -2.035496 & -3.001961 & -1.286532 & -3.162523 & -4.747407 & -0.312585 \\
\hline & 0.122 & 0.14 & 0.239 & 0.243 & 0.309 & 0.06 & 0.065 & 0.138 & 0.07 \\
\hline
\end{tabular}


Table 6 - Percent Change in Predicted Entry With and Without “Distance to Parent” Effects (1993-2001)

\begin{tabular}{|c|c|c|c|c|c|}
\hline IBGE Sector & North & Northeast & Southeast & South & Center-West \\
\hline Metallurgy & 0.17 & -0.05 & -0.05 & 0.03 & 0.08 \\
\hline Machinery & 0.06 & 0.02 & -0.03 & 0.02 & 0.01 \\
\hline Communications and Electronic Equipment & 0.26 & -0.09 & -0.24 & -0.01 & 0.04 \\
\hline Transportation Equipment & 0.22 & 0.03 & -0.13 & -0.05 & 0.02 \\
\hline Wood and Furniture & 0.06 & 0.04 & -0.02 & 0.03 & 0.03 \\
\hline Paper and Publishing & 0.08 & 0.05 & -0.02 & 0.05 & 0.04 \\
\hline Rubber, Tobacco, and Skins & 0.06 & 0.02 & -0.01 & -0.02 & 0.01 \\
\hline Chemicals, Pharmaceuticals, Veterinary \& Perfume Products & 0.10 & 0.08 & -0.03 & 0.04 & 0.05 \\
\hline Textiles & 0.07 & 0.05 & -0.02 & 0.03 & 0.04 \\
\hline Shoes & 0.13 & 0.06 & -0.04 & 0.05 & 0.05 \\
\hline Food, Beverages, and Alcohol & 0.05 & -0.01 & -0.01 & 0.01 & 0.02 \\
\hline Retail & 0.09 & -0.02 & -0.06 & 0.00 & 0.02 \\
\hline Credit Institutions, Insurance, \& Capitalization & 0.54 & -0.31 & -0.47 & -0.12 & -0.15 \\
\hline Real Estate & 0.07 & -0.06 & -0.08 & 0.00 & -0.10 \\
\hline Transportation \& Communication & 0.10 & 0.05 & -0.03 & 0.03 & 0.03 \\
\hline Hotel and Food & 0.10 & 0.02 & -0.04 & 0.04 & 0.06 \\
\hline Medical, Veterinary, and Dentistry Services & 0.17 & 0.08 & -0.08 & 0.04 & 0.04 \\
\hline Education & 0.41 & 0.17 & -0.27 & -0.05 & -0.09 \\
\hline
\end{tabular}


Table 7 - Second Stage Constitutional Fund Coefficient Estimates

\begin{tabular}{|c|c|c|c|}
\hline & (i) & (ii) & (iii) \\
\hline \multicolumn{4}{|l|}{ Manufacturing Sectors } \\
\hline Metallurgy & $\begin{array}{c}-0.653 \\
(-12.95)\end{array}$ & $\begin{array}{c}-0.656 \\
(-13.03)\end{array}$ & $\begin{array}{l}-0.006 \\
(-1.01)\end{array}$ \\
\hline Machinery & $\begin{array}{l}-0.555 \\
(-6.70)\end{array}$ & $\begin{array}{l}-0.572 \\
(-6.91)\end{array}$ & $\begin{array}{l}0.055 \\
(4.22)\end{array}$ \\
\hline Communications and Electronic & -0.250 & -0.250 & 0.015 \\
\hline Equipment & $(-1.76)$ & $(-1.76)$ & $(0.85)$ \\
\hline Transportation Equipment & $\begin{array}{l}-0.660 \\
(-8.70)\end{array}$ & $\begin{array}{l}-0.659 \\
(-8.69)\end{array}$ & $\begin{array}{l}0.032 \\
(3.80)\end{array}$ \\
\hline Wood and Furniture & $\begin{array}{c}-2.684 \\
(-18.53)\end{array}$ & $\begin{array}{c}-2.694 \\
(-18.61)\end{array}$ & $\begin{array}{l}0.024 \\
(2.25)\end{array}$ \\
\hline Paper and Publishing & $\begin{array}{c}-4.157 \\
(-20.68)\end{array}$ & $\begin{array}{c}-4.157 \\
(-20.69)\end{array}$ & $\begin{array}{l}-0.002 \\
(-0.13)\end{array}$ \\
\hline Rubber, Tobacco, and Skins & $\begin{array}{l}-4.574 \\
(-2391)\end{array}$ & $\begin{array}{c}-4.662 \\
(-24.48)\end{array}$ & 0.011 \\
\hline $\begin{array}{l}\text { Chemicals, Pharmaceuticals, } \\
\text { Veterinary \& Perfume Products }\end{array}$ & $\begin{array}{c}-4.125 \\
(-23.16)\end{array}$ & $\begin{array}{c}-4.154 \\
(-23.33)\end{array}$ & $\begin{array}{l}0.013 \\
(0.71)\end{array}$ \\
\hline Textiles & $\begin{array}{c}-3.452 \\
(-23.57)\end{array}$ & $\begin{array}{c}-3.455 \\
(-23.59)\end{array}$ & $\begin{array}{l}0.054 \\
(2.40)\end{array}$ \\
\hline Shoes & $\begin{array}{c}-1.458 \\
(-10.02)\end{array}$ & $\begin{array}{l}-1.440 \\
(-9.90)\end{array}$ & $\begin{array}{l}0.003 \\
(0.14)\end{array}$ \\
\hline Food, Beverages, and Alcohol & $\begin{array}{l}-2.968 \\
(-24.71)\end{array}$ & $\begin{array}{c}-2.969 \\
(-24.72)\end{array}$ & $\begin{array}{l}0.039 \\
(2.70)\end{array}$ \\
\hline \multicolumn{4}{|l|}{ Non-Manufacturing Sectors } \\
\hline Retail & $\begin{array}{l}-0.573 \\
(-6.95)\end{array}$ & $\begin{array}{l}-0.580 \\
(-7.04)\end{array}$ & $\begin{array}{l}0.047 \\
(3.91)\end{array}$ \\
\hline $\begin{array}{l}\text { Credit Institutions, Insurance, \& } \\
\text { Capitalization }\end{array}$ & $\begin{array}{l}0.024 \\
(0.32)\end{array}$ & $\begin{array}{l}0.030 \\
(0.40)\end{array}$ & $\begin{array}{l}0.042 \\
(1.22)\end{array}$ \\
\hline Real Estate & $\begin{array}{l}-0.115 \\
(-3.10)\end{array}$ & $\begin{array}{l}-0.121 \\
(-3.28)\end{array}$ & $\begin{array}{l}-0.054 \\
(-8.78)\end{array}$ \\
\hline Transportation \& Communication & $\begin{array}{c}-0.776 \\
(-10.20)\end{array}$ & $\begin{array}{c}-0.785 \\
(-10.33)\end{array}$ & $\begin{array}{l}0.022 \\
(2.17)\end{array}$ \\
\hline Hotel and Food & $\begin{array}{c}-0.722 \\
(-1266)\end{array}$ & $\begin{array}{c}-0.716 \\
(-1257)\end{array}$ & $\begin{array}{l}0.009 \\
(1.12)\end{array}$ \\
\hline Medical, Veterinary, and Dentistry & -0.372 & -0.396 & -0.026 \\
\hline Education & $\begin{array}{l}-0.184 \\
(-4.98) \\
\end{array}$ & $\begin{array}{l}-0.182 \\
(-4.91) \\
\end{array}$ & $\begin{array}{l}-0.036 \\
(-7.51) \\
\end{array}$ \\
\hline Year Fixed Effects & Yes & Yes & Yes \\
\hline Local Covariates & No & Yes & No \\
\hline Agglomeration Fixed Effects & No & No & Yes \\
\hline
\end{tabular}


Table 8 - Compensating Variation in Distance-to-Parent (km)

From Elimination of Constitutional Fund ${ }^{21}$

(Share of Average Distance to Parent in Parentheses)

\begin{tabular}{|c|c|c|c|c|}
\hline \multirow{2}{*}{ Industry } & \multirow{2}{*}{$\begin{array}{c}\text { Average } \\
\text { Distance to } \\
\text { Parent }(\mathrm{km})\end{array}$} & \multicolumn{3}{|c|}{ Region } \\
\hline & & North & Northeast & Center-West \\
\hline Machinery & 143.50 & $\begin{array}{c}27.96 \\
(19.48)\end{array}$ & $\begin{array}{c}21.97 \\
(15.31)\end{array}$ & $\begin{array}{c}37.36 \\
(26.03)\end{array}$ \\
\hline $\begin{array}{l}\text { Transportation } \\
\text { Equipment }\end{array}$ & 119.83 & $\begin{array}{l}12.67 \\
(10.57)\end{array}$ & $\begin{array}{l}9.96 \\
(8.31)\end{array}$ & $\begin{array}{c}16.93 \\
(14.13)\end{array}$ \\
\hline $\begin{array}{l}\text { Wood and } \\
\text { Furniture }\end{array}$ & 80.11 & $\begin{array}{c}8.54 \\
(10.66)\end{array}$ & $\begin{array}{l}6.71 \\
(8.38)\end{array}$ & $\begin{array}{c}11.41 \\
(14.24)\end{array}$ \\
\hline Textiles & 67.00 & $\begin{array}{c}11.25 \\
(16.79)\end{array}$ & $\begin{array}{c}8.84 \\
(13.19)\end{array}$ & $\begin{array}{c}15.03 \\
(22.43)\end{array}$ \\
\hline $\begin{array}{l}\text { Food, Beverages, } \\
\text { and Alcohol }\end{array}$ & 79.07 & $\begin{array}{l}5.09 \\
(6.44)\end{array}$ & $\begin{array}{c}4.00 \\
(5.06)\end{array}$ & $\begin{array}{c}6.79 \\
(8.59)\end{array}$ \\
\hline \multicolumn{2}{|c|}{ Average CF Per Employee } & 788.17 & 619.30 & 1052.91 \\
\hline
\end{tabular}

${ }^{21}$ Evaluated at the average CF allocation per employee by region, and using the 1996 first-stage parameter estimate on distance-to-parent. 
Table 9(a) - Other Determinants of Entry Behavior

\begin{tabular}{|c|c|c|c|c|c|c|c|c|}
\hline & \multicolumn{4}{|c|}{ Metallurgy } & \multicolumn{4}{|c|}{ Machinery } \\
\hline & Mean (High) & Mean (Low) & Difference & t-statistic & Mean (High) & Mean (Low) & Difference & t-statistic \\
\hline Population & 466848.86 & 284228.02 & 182620.84 & 1.21 & 516687.30 & 234764.29 & 281923.01 & 1.88 \\
\hline Transportation Cost & 1188.97 & 1722.15 & -533.18 & -4.22 & 1162.14 & 1748.77 & -586.63 & -4.67 \\
\hline Human Development Index & 0.70 & 0.64 & 0.06 & 5.93 & 0.70 & 0.64 & 0.07 & 6.33 \\
\hline Average Education ( > 25 Years) & 4.80 & 3.97 & 0.83 & 5.10 & 4.85 & 3.92 & 0.93 & 5.82 \\
\hline$\%$ Garbage Collection & 75.87 & 66.45 & 9.42 & 3.64 & 75.58 & 66.73 & 8.84 & 3.40 \\
\hline \% Electric Lighting & 89.47 & 81.60 & 7.87 & 3.93 & 90.16 & 80.92 & 9.24 & 4.66 \\
\hline$\%$ Piped Water & 78.51 & 63.02 & 15.49 & 5.22 & 78.99 & 62.54 & 16.45 & 5.58 \\
\hline Theil Index & 0.54 & 0.55 & -0.01 & -0.72 & 0.54 & 0.56 & -0.02 & -1.54 \\
\hline \multicolumn{9}{|l|}{ Employment: } \\
\hline Mining & 673.71 & 449.67 & 224.04 & 1.39 & 758.82 & 365.20 & 393.63 & 2.47 \\
\hline Agriculture & 13380.95 & 15121.28 & -1740.33 & -0.60 & 15196.59 & 13319.29 & 1877.30 & 0.65 \\
\hline Commerce & 28349.58 & 17182.24 & 11167.34 & 1.22 & 31530.09 & 14025.64 & 17504.45 & 1.92 \\
\hline Construction & 14092.56 & 8593.65 & 5498.91 & 1.24 & 15781.35 & 6917.56 & 8863.79 & 2.02 \\
\hline Finance & 3515.89 & 1573.73 & 1942.16 & 1.25 & 3893.04 & 1199.41 & 2693.64 & 1.73 \\
\hline Fishing & 411.32 & 392.17 & 19.14 & 0.16 & 449.40 & 354.37 & 95.03 & 0.80 \\
\hline Manufacturing & 18452.14 & 10015.74 & 8436.40 & 1.23 & 21245.28 & 7243.59 & 14001.69 & 2.05 \\
\hline - Chemicals & 2183.99 & 691.31 & 1492.68 & 1.35 & 2325.42 & 550.94 & 1774.48 & 1.61 \\
\hline - Electrical Equipment & 1706.77 & 361.24 & 1345.52 & 1.59 & 1822.93 & 245.95 & 1576.98 & 1.87 \\
\hline - Food & 4420.57 & 2667.35 & 1753.22 & 1.28 & 5077.45 & 2015.40 & 3062.05 & 2.26 \\
\hline - Furniture & 1898.86 & 990.70 & 908.16 & 1.40 & 2077.24 & 813.66 & 1263.58 & 1.96 \\
\hline - Leather & 179.99 & 228.91 & -48.92 & -0.32 & 326.40 & 83.60 & 242.80 & 1.57 \\
\hline - Machinery & 1362.23 & 434.29 & 927.95 & 1.65 & 1513.27 & 284.39 & 1228.87 & 2.20 \\
\hline - Metal & 6040.52 & 2124.69 & 3915.83 & 1.53 & 6781.55 & 1389.23 & 5392.32 & 2.12 \\
\hline - Paper & 739.31 & 203.96 & 535.35 & 1.65 & 805.33 & 138.44 & 666.88 & 2.07 \\
\hline - Petroleum & 268.30 & 215.14 & 53.16 & 0.29 & 322.99 & 160.85 & 162.14 & 0.87 \\
\hline - Plastics & 1459.48 & 376.63 & 1082.85 & 1.24 & 1619.62 & 217.69 & 1401.93 & 1.61 \\
\hline - Printing & 1638.22 & 534.66 & 1103.56 & 1.28 & 1789.23 & 384.79 & 1404.44 & 1.63 \\
\hline - Textiles & 5528.35 & 1853.26 & 3675.09 & 1.69 & 5886.08 & 1498.22 & 4387.85 & 2.02 \\
\hline - Tobacco & 79.02 & 145.51 & -66.50 & -0.64 & 174.00 & 51.24 & 122.76 & 1.18 \\
\hline - Transportation Equipment & 2528.78 & 794.89 & 1733.89 & 1.36 & 2714.15 & 610.92 & 2103.23 & 1.66 \\
\hline - Wood Products & 1173.11 & 881.09 & 292.02 & 0.98 & 1238.77 & 815.91 & 422.86 & 1.43 \\
\hline
\end{tabular}


Table 9(b) - Other Determinants of Entry Behavior

\begin{tabular}{|c|c|c|c|c|c|c|c|c|}
\hline & \multicolumn{4}{|c|}{ Communication \& Electrical Equipment } & \multicolumn{4}{|c|}{ Transportation Equipment } \\
\hline & Mean (High) & Mean (Low) & Difference & t-statistic & Mean (High) & Mean (Low) & Difference & t-statistic \\
\hline Population & 492318.75 & 258949.62 & 233369.13 & 1.55 & 455359.19 & 295631.29 & 159727.90 & 1.06 \\
\hline Transportation Cost & 1285.33 & 1626.51 & -341.18 & -2.65 & 1227.90 & 1683.51 & -455.61 & -3.57 \\
\hline Human Development Index & 0.69 & 0.65 & 0.05 & 4.20 & 0.70 & 0.64 & 0.06 & 5.29 \\
\hline Average Education ( > 25 Years) & 4.71 & 4.06 & 0.65 & 3.93 & 4.79 & 3.98 & 0.82 & 5.01 \\
\hline$\%$ Garbage Collection & 73.39 & 68.90 & 4.49 & 1.70 & 76.03 & 66.28 & 9.75 & 3.77 \\
\hline \% Electric Lighting & 88.95 & 82.12 & 6.82 & 3.38 & 89.74 & 81.34 & 8.40 & 4.21 \\
\hline$\%$ Piped Water & 76.19 & 65.33 & 10.86 & 3.57 & 78.24 & 63.29 & 14.94 & 5.02 \\
\hline Theil Index & 0.55 & 0.54 & 0.01 & 1.08 & 0.55 & 0.55 & 0.00 & 0.04 \\
\hline \multicolumn{9}{|l|}{ Employment: } \\
\hline Mining & 711.82 & 411.85 & 299.96 & 1.87 & 628.45 & 494.59 & 133.86 & 0.83 \\
\hline Agriculture & 16666.24 & 11860.70 & 4805.54 & 1.68 & 14576.50 & 13934.72 & 641.78 & 0.22 \\
\hline Commerce & 29868.52 & 15674.72 & 14193.80 & 1.55 & 27672.86 & 17853.87 & 9818.99 & 1.07 \\
\hline Construction & 14820.09 & 7871.59 & 6948.51 & 1.58 & 13555.70 & 9126.47 & 4429.23 & 1.00 \\
\hline Finance & 3696.21 & 1394.76 & 2301.45 & 1.48 & 3463.22 & 1626.00 & 1837.22 & 1.18 \\
\hline Fishing & 472.14 & 331.80 & 140.34 & 1.18 & 406.90 & 396.56 & 10.34 & 0.09 \\
\hline Manufacturing & 18879.96 & 9591.13 & 9288.83 & 1.36 & 18382.39 & 10084.96 & 8297.43 & 1.21 \\
\hline - Chemicals & 2085.70 & 788.86 & 1296.84 & 1.17 & 2044.73 & 829.52 & 1215.21 & 1.10 \\
\hline - Electrical Equipment & 1628.42 & 438.99 & 1189.43 & 1.41 & 1629.47 & 437.95 & 1191.51 & 1.41 \\
\hline - Food & 4469.39 & 2618.89 & 1850.49 & 1.36 & 4505.27 & 2583.29 & 1921.98 & 1.41 \\
\hline - Furniture & 1937.45 & 952.41 & 985.04 & 1.52 & 1835.49 & 1053.59 & 781.90 & 1.21 \\
\hline - Leather & 306.58 & 103.27 & 203.31 & 1.32 & 310.12 & 99.76 & 210.36 & 1.36 \\
\hline - Machinery & 1269.36 & 526.46 & 742.90 & 1.32 & 1311.61 & 484.53 & 827.09 & 1.47 \\
\hline - Metal & 5955.74 & 2208.83 & 3746.91 & 1.46 & 5689.35 & 2473.21 & 3216.14 & 1.26 \\
\hline - Paper & 670.37 & 272.38 & 397.99 & 1.23 & 659.97 & 282.71 & 377.26 & 1.16 \\
\hline - Petroleum & 282.92 & 200.62 & 82.31 & 0.44 & 281.02 & 202.50 & 78.52 & 0.42 \\
\hline - Plastics & 1434.48 & 401.44 & 1033.05 & 1.19 & 1451.55 & 384.50 & 1067.04 & 1.22 \\
\hline - Printing & 1668.93 & 504.18 & 1164.75 & 1.35 & 1620.70 & 552.05 & 1068.66 & 1.24 \\
\hline - Textiles & 4650.24 & 2724.77 & 1925.47 & 0.88 & 5064.33 & 2313.79 & 2750.55 & 1.26 \\
\hline - Tobacco & 163.90 & 61.26 & 102.64 & 0.99 & 169.23 & 55.98 & 113.25 & 1.09 \\
\hline - Transportation Equipment & 2320.51 & 1001.60 & 1318.91 & 1.03 & 2340.65 & 981.61 & 1359.04 & 1.07 \\
\hline - Wood Products & 1241.92 & 812.79 & 429.13 & 1.45 & 1036.76 & 1016.41 & 20.35 & 0.07 \\
\hline
\end{tabular}


Table 9(c) - Other Determinants of Entry Behavior

\begin{tabular}{|c|c|c|c|c|c|c|c|c|}
\hline & \multicolumn{4}{|c|}{ Wood \& Furniture } & \multicolumn{4}{|c|}{ Paper \& Publishing } \\
\hline & Mean (High) & Mean (Low) & Difference & t-statistic & Mean (High) & Mean (Low) & Difference & t-statistic \\
\hline Population & 443593.76 & 307308.26 & 136285.49 & 0.90 & 414033.86 & 336645.90 & 77387.96 & 0.51 \\
\hline Transportation Cost & 1113.73 & 1796.82 & -683.09 & -5.52 & 1162.24 & 1748.68 & -586.44 & -4.67 \\
\hline Human Development Index & 0.70 & 0.64 & 0.06 & 5.52 & 0.70 & 0.64 & 0.06 & 5.88 \\
\hline Average Education ( > 25 Years) & 4.77 & 4.00 & 0.77 & 4.73 & 4.80 & 3.97 & 0.83 & 5.09 \\
\hline$\%$ Garbage Collection & 76.70 & 65.62 & 11.09 & 4.32 & 75.16 & 67.14 & 8.02 & 3.07 \\
\hline \% Electric Lighting & 89.71 & 81.37 & 8.33 & 4.17 & 89.79 & 81.28 & 8.51 & 4.27 \\
\hline$\%$ Piped Water & 78.85 & 62.68 & 16.17 & 5.48 & 78.39 & 63.14 & 15.25 & 5.14 \\
\hline Theil Index & 0.53 & 0.56 & -0.03 & -2.31 & 0.53 & 0.57 & -0.04 & -3.57 \\
\hline \multicolumn{9}{|l|}{ Employment: } \\
\hline Mining & 590.54 & 532.22 & 58.32 & 0.36 & 549.14 & 573.30 & -24.16 & -0.15 \\
\hline Agriculture & 12098.38 & 16394.21 & -4295.84 & -1.50 & 13036.39 & 15463.25 & -2426.86 & -0.84 \\
\hline Commerce & 26940.14 & 18581.08 & 8359.06 & 0.91 & 24891.10 & 20614.72 & 4276.38 & 0.47 \\
\hline Construction & 13356.35 & 9324.32 & 4032.02 & 0.91 & 12304.95 & 10367.82 & 1937.14 & 0.44 \\
\hline Finance & 3419.20 & 1669.69 & 1749.51 & 1.12 & 3137.47 & 1949.29 & 1188.18 & 0.76 \\
\hline Fishing & 352.66 & 450.39 & -97.72 & -0.82 & 384.63 & 418.66 & -34.03 & -0.29 \\
\hline Manufacturing & 18051.95 & 10412.92 & 7639.03 & 1.11 & 16974.39 & 11482.38 & 5492.01 & 0.80 \\
\hline - Chemicals & 2294.27 & 581.86 & 1712.41 & 1.55 & 2101.41 & 773.27 & 1328.13 & 1.20 \\
\hline - Electrical Equipment & 1777.38 & 291.16 & 1486.22 & 1.76 & 1370.95 & 694.53 & 676.41 & 0.80 \\
\hline - Food & 4264.71 & 2822.03 & 1442.68 & 1.06 & 4002.42 & 3082.35 & 920.08 & 0.67 \\
\hline - Furniture & 1838.81 & 1050.30 & 788.51 & 1.22 & 1648.16 & 1239.52 & 408.64 & 0.63 \\
\hline - Leather & 204.33 & 204.76 & -0.43 & 0.00 & 177.42 & 231.47 & -54.05 & -0.35 \\
\hline - Machinery & 1348.86 & 447.56 & 901.29 & 1.61 & 1284.97 & 510.97 & 774.00 & 1.38 \\
\hline - Metal & 5833.08 & 2330.56 & 3502.52 & 1.37 & 5616.33 & 2545.69 & 3070.64 & 1.20 \\
\hline - Paper & 745.12 & 198.20 & 546.93 & 1.69 & 666.83 & 275.90 & 390.92 & 1.21 \\
\hline - Petroleum & 274.90 & 208.58 & 66.32 & 0.36 & 250.90 & 232.40 & 18.50 & 0.10 \\
\hline - Plastics & 1493.00 & 343.36 & 1149.64 & 1.32 & 1374.67 & 460.80 & 913.86 & 1.05 \\
\hline - Printing & 1600.11 & 572.49 & 1027.62 & 1.19 & 1481.15 & 690.55 & 790.60 & 0.92 \\
\hline - Textiles & 4867.34 & 2509.30 & 2358.04 & 1.08 & 4930.39 & 2446.73 & 2483.66 & 1.14 \\
\hline - Tobacco & 88.67 & 135.93 & -47.27 & -0.45 & 71.58 & 152.89 & -81.30 & -0.78 \\
\hline - Transportation Equipment & 2565.52 & 758.44 & 1807.08 & 1.42 & 2446.17 & 876.88 & 1569.29 & 1.23 \\
\hline - Wood Products & 1046.77 & 1006.47 & 40.30 & 0.14 & 1026.80 & 1026.29 & 0.51 & 0.00 \\
\hline
\end{tabular}


Table 9(d) - Other Determinants of Entry Behavior

\begin{tabular}{|c|c|c|c|c|c|c|c|c|}
\hline & \multicolumn{4}{|c|}{ Rubber, Tobacco, \& Skins } & \multicolumn{4}{|c|}{$\begin{array}{c}\text { Chemicals, Pharmaceuticals, Veterinary Products, and } \\
\text { Perfumes }\end{array}$} \\
\hline & Mean (High) & Mean (Low) & Difference & t-statistic & Mean (High) & Mean (Low) & Difference & t-statistic \\
\hline Population & 483047.89 & 268150.77 & 214897.12 & 1.43 & 473604.28 & 277523.38 & 196080.90 & 1.30 \\
\hline Transportation Cost & 1143.61 & 1767.16 & -623.55 & -4.99 & 974.49 & 1935.01 & -960.53 & -8.25 \\
\hline Human Development Index & 0.70 & 0.64 & 0.06 & 5.68 & 0.71 & 0.63 & 0.09 & 8.57 \\
\hline Average Education ( > 25 Years) & 4.82 & 3.95 & 0.87 & 5.35 & 4.95 & 3.82 & 1.13 & 7.27 \\
\hline$\%$ Garbage Collection & 76.66 & 65.65 & 11.01 & 4.29 & 79.06 & 63.28 & 15.78 & 6.39 \\
\hline \% Electric Lighting & 90.25 & 80.83 & 9.42 & 4.76 & 92.09 & 79.00 & 13.09 & 6.90 \\
\hline$\%$ Piped Water & 79.31 & 62.22 & 17.09 & 5.83 & 82.43 & 59.14 & 23.29 & 8.43 \\
\hline Theil Index & 0.53 & 0.56 & -0.03 & -2.40 & 0.53 & 0.56 & -0.03 & -2.56 \\
\hline \multicolumn{9}{|l|}{ Employment: } \\
\hline Mining & 652.50 & 470.73 & 181.77 & 1.13 & 661.64 & 461.65 & 199.99 & 1.24 \\
\hline Agriculture & 14898.50 & 13615.14 & 1283.36 & 0.45 & 14212.53 & 14295.95 & -83.42 & -0.03 \\
\hline Commerce & 29574.33 & 15966.70 & 13607.63 & 1.49 & 28876.39 & 16659.39 & 12217.00 & 1.33 \\
\hline Construction & 14584.53 & 8105.38 & 6479.15 & 1.47 & 14538.91 & 8150.66 & 6388.25 & 1.45 \\
\hline Finance & 3737.89 & 1353.39 & 2384.51 & 1.53 & 3706.11 & 1384.93 & 2321.18 & 1.49 \\
\hline Fishing & 381.59 & 421.68 & -40.09 & -0.34 & 337.11 & 465.82 & -128.71 & -1.08 \\
\hline Manufacturing & 20171.79 & 8309.01 & 11862.78 & 1.74 & 19602.23 & 8874.29 & 10727.94 & 1.57 \\
\hline - Chemicals & 2346.03 & 530.49 & 1815.54 & 1.65 & 2236.57 & 639.13 & 1597.44 & 1.45 \\
\hline - Electrical Equipment & 1809.98 & 258.80 & 1551.17 & 1.84 & 1515.08 & 551.48 & 963.60 & 1.14 \\
\hline - Food & 4905.85 & 2185.72 & 2720.13 & 2.00 & 4924.77 & 2166.94 & 2757.84 & 2.03 \\
\hline - Furniture & 1984.97 & 905.24 & 1079.73 & 1.67 & 2004.71 & 885.65 & 1119.06 & 1.73 \\
\hline - Leather & 323.61 & 86.38 & 237.23 & 1.54 & 320.58 & 89.38 & 231.19 & 1.50 \\
\hline - Machinery & 1479.98 & 317.42 & 1162.56 & 2.08 & 1406.05 & 390.80 & 1015.24 & 1.81 \\
\hline - Metal & 6300.22 & 1866.94 & 4433.28 & 1.73 & 6241.39 & 1925.32 & 4316.08 & 1.69 \\
\hline - Paper & 754.97 & 188.42 & 566.55 & 1.75 & 706.72 & 236.31 & 470.41 & 1.45 \\
\hline - Petroleum & 314.73 & 169.05 & 145.69 & 0.78 & 309.07 & 174.67 & 134.40 & 0.72 \\
\hline - Plastics & 1603.98 & 233.21 & 1370.77 & 1.58 & 1511.15 & 325.35 & 1185.81 & 1.36 \\
\hline - Printing & 1731.77 & 441.82 & 1289.95 & 1.50 & 1704.21 & 469.17 & 1235.05 & 1.43 \\
\hline - Textiles & 5586.50 & 1795.55 & 3790.95 & 1.74 & 5263.34 & 2116.28 & 3147.06 & 1.44 \\
\hline - Tobacco & 190.86 & 34.50 & 156.36 & 1.51 & 171.97 & 53.26 & 118.71 & 1.14 \\
\hline - Transportation Equipment & 2517.83 & 805.77 & 1712.06 & 1.35 & 2760.38 & 565.04 & 2195.34 & 1.73 \\
\hline - Wood Products & 1126.27 & 927.57 & 198.70 & 0.67 & 1045.02 & 1008.22 & 36.80 & 0.12 \\
\hline
\end{tabular}


Table 9(e) - Other Determinants of Entry Behavior

\begin{tabular}{|c|c|c|c|c|c|c|c|c|}
\hline & \multicolumn{4}{|c|}{ Textiles } & \multicolumn{4}{|c|}{ Shoes } \\
\hline & Mean (High) & Mean (Low) & Difference & t-statistic & Mean (High) & Mean (Low) & Difference & t-statistic \\
\hline Population & 486735.45 & 264490.95 & 222244.50 & 1.48 & 467955.85 & 283129.35 & 184826.50 & 1.23 \\
\hline Transportation Cost & 1028.30 & 1881.60 & -853.30 & -7.13 & 1133.79 & 1776.91 & -643.12 & -5.17 \\
\hline Human Development Index & 0.71 & 0.63 & 0.08 & 8.12 & 0.70 & 0.64 & 0.07 & 6.34 \\
\hline Average Education ( > 25 Years) & 4.93 & 3.85 & 1.08 & 6.90 & 4.82 & 3.95 & 0.87 & 5.40 \\
\hline$\%$ Garbage Collection & 77.68 & 64.64 & 13.04 & 5.15 & 76.87 & 65.45 & 11.41 & 4.46 \\
\hline \% Electric Lighting & 91.38 & 79.71 & 11.67 & 6.04 & 90.35 & 80.73 & 9.63 & 4.88 \\
\hline$\%$ Piped Water & 81.53 & 60.02 & 21.51 & 7.63 & 79.67 & 61.87 & 17.79 & 6.10 \\
\hline Theil Index & 0.53 & 0.56 & -0.03 & -2.64 & 0.53 & 0.56 & -0.03 & -2.66 \\
\hline \multicolumn{9}{|l|}{ Employment: } \\
\hline Mining & 697.28 & 426.28 & 271.00 & 1.69 & 654.02 & 469.22 & 184.81 & 1.15 \\
\hline Agriculture & 13842.46 & 14663.24 & -820.79 & -0.29 & 13776.38 & 14728.82 & -952.45 & -0.33 \\
\hline Commerce & 29789.32 & 15753.32 & 14036.00 & 1.53 & 28316.90 & 17214.67 & 11102.23 & 1.21 \\
\hline Construction & 15032.99 & 7660.29 & 7372.71 & 1.67 & 14285.13 & 8402.52 & 5882.61 & 1.33 \\
\hline Finance & 3808.41 & 1283.40 & 2525.01 & 1.62 & 3643.64 & 1446.94 & 2196.70 & 1.41 \\
\hline Fishing & 326.52 & 476.33 & -149.82 & -1.26 & 345.36 & 457.63 & -112.27 & -0.94 \\
\hline Manufacturing & 20816.44 & 7669.21 & 13147.22 & 1.93 & 18956.71 & 9514.96 & 9441.76 & 1.38 \\
\hline - Chemicals & 2372.02 & 504.70 & 1867.31 & 1.70 & 2307.25 & 568.98 & 1738.27 & 1.58 \\
\hline - Electrical Equipment & 1609.24 & 458.03 & 1151.21 & 1.36 & 1552.19 & 514.65 & 1037.54 & 1.23 \\
\hline - Food & 4868.47 & 2222.82 & 2645.65 & 1.95 & 4593.53 & 2495.69 & 2097.84 & 1.54 \\
\hline - Furniture & 2069.77 & 821.08 & 1248.68 & 1.94 & 1951.68 & 938.28 & 1013.40 & 1.57 \\
\hline - Leather & 339.36 & 70.74 & 268.61 & 1.74 & 202.58 & 206.49 & -3.91 & -0.03 \\
\hline - Machinery & 1524.29 & 273.45 & 1250.84 & 2.24 & 1413.53 & 383.38 & 1030.15 & 1.84 \\
\hline - Metal & 6713.88 & 1456.39 & 5257.49 & 2.06 & 6190.96 & 1975.37 & 4215.59 & 1.65 \\
\hline - Paper & 777.34 & 166.22 & 611.12 & 1.89 & 744.63 & 198.68 & 545.94 & 1.69 \\
\hline - Petroleum & 323.36 & 160.48 & 162.88 & 0.88 & 288.85 & 194.74 & 94.11 & 0.51 \\
\hline - Plastics & 1607.74 & 229.48 & 1378.26 & 1.59 & 1503.17 & 333.26 & 1169.91 & 1.34 \\
\hline - Printing & 1751.05 & 422.68 & 1328.36 & 1.54 & 1670.70 & 502.42 & 1168.28 & 1.36 \\
\hline - Textiles & 5899.49 & 1484.91 & 4414.58 & 2.03 & 5501.81 & 1879.60 & 3622.21 & 1.66 \\
\hline - Tobacco & 184.08 & 41.23 & 142.85 & 1.38 & 82.43 & 142.12 & -59.69 & -0.57 \\
\hline - Transportation Equipment & 2895.75 & 430.68 & 2465.07 & 1.94 & 2694.83 & 630.10 & 2064.73 & 1.63 \\
\hline - Wood Products & 1064.50 & 988.88 & 75.62 & 0.25 & 1042.19 & 1011.02 & 31.17 & 0.10 \\
\hline
\end{tabular}


Table 9(f) - Other Determinants of Entry Behavior

\begin{tabular}{|c|c|c|c|c|c|c|c|c|}
\hline & \multicolumn{4}{|c|}{ Food, Beverages, \& Alcohol } & \multicolumn{4}{|c|}{ Retail } \\
\hline & Mean (High) & Mean (Low) & Difference & t-statistic & Mean (High) & Mean (Low) & Difference & t-statistic \\
\hline Population & 495846.95 & 255447.95 & 240398.99 & 1.60 & 433239.95 & 317584.23 & 115655.72 & 0.77 \\
\hline Transportation Cost & 995.48 & 1914.18 & -918.69 & -7.80 & 1179.14 & 1731.90 & -552.75 & -4.38 \\
\hline Human Development Index & 0.71 & 0.63 & 0.08 & 7.76 & 0.70 & 0.64 & 0.06 & 5.49 \\
\hline Average Education ( > 25 Years) & 4.93 & 3.84 & 1.10 & 7.00 & 4.78 & 3.99 & 0.78 & 4.79 \\
\hline$\%$ Garbage Collection & 78.53 & 63.80 & 14.73 & 5.90 & 75.94 & 66.37 & 9.57 & 3.70 \\
\hline \% Electric Lighting & 91.75 & 79.34 & 12.41 & 6.48 & 89.76 & 81.32 & 8.44 & 4.23 \\
\hline$\%$ Piped Water & 82.22 & 59.34 & 22.88 & 8.24 & 78.40 & 63.14 & 15.26 & 5.14 \\
\hline Theil Index & 0.53 & 0.56 & -0.03 & -2.74 & 0.54 & 0.56 & -0.01 & -1.29 \\
\hline \multicolumn{9}{|l|}{ Employment: } \\
\hline Mining & 680.69 & 442.74 & 237.95 & 1.48 & 606.79 & 516.09 & 90.70 & 0.56 \\
\hline Agriculture & 12906.25 & 15592.41 & -2686.15 & -0.93 & 12567.59 & 15928.53 & -3360.94 & -1.17 \\
\hline Commerce & 30748.74 & 14801.12 & 15947.62 & 1.74 & 26185.04 & 19330.50 & 6854.54 & 0.75 \\
\hline Construction & 15649.48 & 7048.43 & 8601.05 & 1.96 & 12946.73 & 9730.86 & 3215.87 & 0.73 \\
\hline Finance & 3971.66 & 1121.38 & 2850.29 & 1.83 & 3269.41 & 1818.35 & 1451.05 & 0.93 \\
\hline Fishing & 327.31 & 475.55 & -148.24 & -1.25 & 355.21 & 447.85 & -92.64 & -0.78 \\
\hline Manufacturing & 21249.27 & 7239.64 & 14009.63 & 2.06 & 17026.47 & 11430.69 & 5595.78 & 0.82 \\
\hline - Chemicals & 2454.58 & 422.76 & 2031.83 & 1.85 & 2150.39 & 724.66 & 1425.74 & 1.29 \\
\hline - Electrical Equipment & 1668.53 & 399.19 & 1269.34 & 1.50 & 1672.45 & 395.30 & 1277.15 & 1.51 \\
\hline - Food & 4938.75 & 2153.06 & 2785.69 & 2.05 & 4142.00 & 2943.82 & 1198.18 & 0.88 \\
\hline - Furniture & 2135.24 & 756.10 & 1379.14 & 2.14 & 1751.83 & 1136.63 & 615.19 & 0.95 \\
\hline - Leather & 331.16 & 78.88 & 252.28 & 1.64 & 174.01 & 234.85 & -60.84 & -0.39 \\
\hline - Machinery & 1582.57 & 215.61 & 1366.96 & 2.45 & 1293.08 & 502.92 & 790.17 & 1.41 \\
\hline - Metal & 6982.93 & 1189.36 & 5793.58 & 2.28 & 5566.11 & 2595.52 & 2970.59 & 1.16 \\
\hline - Paper & 802.66 & 141.09 & 661.57 & 2.05 & 726.78 & 216.40 & 510.38 & 1.58 \\
\hline - Petroleum & 339.57 & 144.40 & 195.17 & 1.05 & 255.36 & 227.98 & 27.38 & 0.15 \\
\hline - Plastics & 1615.04 & 222.24 & 1392.80 & 1.60 & 1379.28 & 456.23 & 923.05 & 1.06 \\
\hline - Printing & 1810.45 & 363.73 & 1446.72 & 1.68 & 1519.68 & 652.31 & 867.37 & 1.00 \\
\hline - Textiles & 6042.16 & 1343.31 & 4698.84 & 2.17 & 4859.61 & 2516.98 & 2342.63 & 1.07 \\
\hline - Tobacco & 194.84 & 30.56 & 164.28 & 1.59 & 69.76 & 154.70 & -84.94 & -0.82 \\
\hline - Transportation Equipment & 2946.64 & 380.17 & 2566.47 & 2.03 & 2481.16 & 842.16 & 1639.00 & 1.29 \\
\hline - Wood Products & 1071.26 & 982.17 & 89.09 & 0.30 & 1012.93 & 1040.06 & -27.13 & -0.09 \\
\hline
\end{tabular}


Table 9(g) - Other Determinants of Entry Behavior

\begin{tabular}{|c|c|c|c|c|c|c|c|c|}
\hline & \multicolumn{4}{|c|}{ Credit Institutions, Insurance, \& Capitalization } & \multicolumn{4}{|c|}{ Real Estate } \\
\hline & Mean (High) & Mean (Low) & Difference & t-statistic & Mean (High) & Mean (Low) & Difference & t-statistic \\
\hline Population & 494480.52 & 256804.11 & 237676.40 & 1.58 & 405143.48 & 345469.44 & 59674.03 & 0.40 \\
\hline Transportation Cost & 1339.22 & 1573.02 & -233.80 & -1.80 & 1331.17 & 1581.02 & -249.85 & -1.93 \\
\hline Human Development Index & 0.69 & 0.65 & 0.05 & 4.31 & 0.69 & 0.65 & 0.05 & 4.14 \\
\hline Average Education ( > 25 Years) & 4.72 & 4.06 & 0.66 & 3.98 & 4.70 & 4.08 & 0.62 & 3.74 \\
\hline$\%$ Garbage Collection & 73.41 & 68.88 & 4.53 & 1.71 & 72.53 & 69.75 & 2.78 & 1.05 \\
\hline \% Electric Lighting & 88.14 & 82.92 & 5.22 & 2.56 & 88.28 & 82.79 & 5.49 & 2.70 \\
\hline$\%$ Piped Water & 74.99 & 66.52 & 8.47 & 2.76 & 75.54 & 65.98 & 9.56 & 3.13 \\
\hline Theil Index & 0.55 & 0.55 & 0.00 & -0.39 & 0.55 & 0.55 & 0.00 & -0.15 \\
\hline \multicolumn{9}{|l|}{ Employment: } \\
\hline Mining & 694.68 & 428.86 & 265.81 & 1.66 & 652.35 & 470.87 & 181.49 & 1.13 \\
\hline Agriculture & 16372.89 & 12151.83 & 4221.06 & 1.47 & 15174.62 & 13341.09 & 1833.53 & 0.64 \\
\hline Commerce & 30046.86 & 15497.72 & 14549.14 & 1.59 & 24272.36 & 21228.80 & 3043.56 & 0.33 \\
\hline Construction & 14653.68 & 8036.75 & 6616.92 & 1.50 & 12034.50 & 10636.23 & 1398.28 & 0.32 \\
\hline Finance & 3656.77 & 1433.90 & 2222.87 & 1.43 & 2687.67 & 2395.71 & 291.96 & 0.19 \\
\hline Fishing & 491.92 & 312.17 & 179.75 & 1.51 & 406.32 & 397.13 & 9.19 & 0.08 \\
\hline Manufacturing & 19516.73 & 8959.15 & 10557.58 & 1.54 & 16028.34 & 12421.31 & 3607.03 & 0.53 \\
\hline - Chemicals & 2247.27 & 628.51 & 1618.77 & 1.47 & 1680.43 & 1191.09 & 489.34 & 0.44 \\
\hline - Electrical Equipment & 1726.04 & 342.11 & 1383.93 & 1.64 & 1417.47 & 648.36 & 769.11 & 0.91 \\
\hline - Food & 4845.52 & 2245.59 & 2599.93 & 1.91 & 3748.35 & 3334.51 & 413.84 & 0.30 \\
\hline - Furniture & 1934.37 & 955.46 & 978.91 & 1.51 & 1651.33 & 1236.38 & 414.95 & 0.64 \\
\hline - Leather & 305.27 & 104.57 & 200.70 & 1.30 & 142.03 & 266.59 & -124.56 & -0.80 \\
\hline - Machinery & 1417.30 & 379.63 & 1037.67 & 1.85 & 1052.18 & 742.01 & 310.17 & 0.55 \\
\hline - Metal & 6015.12 & 2149.89 & 3865.23 & 1.51 & 4877.16 & 3279.29 & 1597.87 & 0.62 \\
\hline - Paper & 750.68 & 192.68 & 558.01 & 1.73 & 564.99 & 376.97 & 188.02 & 0.58 \\
\hline - Petroleum & 297.14 & 186.50 & 110.64 & 0.60 & 134.36 & 348.06 & -213.70 & -1.15 \\
\hline - Plastics & 1509.14 & 327.35 & 1181.79 & 1.36 & 1180.78 & 653.23 & 527.55 & 0.60 \\
\hline - Printing & 1686.61 & 486.63 & 1199.98 & 1.39 & 1283.51 & 886.71 & 396.80 & 0.46 \\
\hline - Textiles & 4980.33 & 2397.16 & 2583.18 & 1.18 & 4399.32 & 2973.80 & 1425.53 & 0.65 \\
\hline - Tobacco & 170.25 & 54.96 & 115.29 & 1.11 & 53.64 & 170.70 & -117.06 & -1.13 \\
\hline - Transportation Equipment & 2444.80 & 878.24 & 1566.56 & 1.23 & 2043.08 & 1276.94 & 766.14 & 0.60 \\
\hline - Wood Products & 1244.79 & 809.94 & 434.84 & 1.47 & 1189.04 & 865.28 & 323.76 & 1.09 \\
\hline
\end{tabular}


Table 9(h) - Other Determinants of Entry Behavior

\begin{tabular}{|c|c|c|c|c|c|c|c|c|}
\hline & \multicolumn{4}{|c|}{ Transportation \& Communication } & \multicolumn{4}{|c|}{ Hotel, Food, Repair \& Publishing Services } \\
\hline & Mean (High) & Mean (Low) & Difference & t-statistic & Mean (High) & Mean (Low) & Difference & t-statistic \\
\hline Population & 509778.11 & 241621.53 & 268156.58 & 1.79 & 516224.73 & 235223.39 & 281001.34 & 1.87 \\
\hline Transportation Cost & 1122.93 & 1787.69 & -664.76 & -5.36 & 1170.15 & 1740.83 & -570.68 & -4.54 \\
\hline Human Development Index & 0.71 & 0.63 & 0.08 & 7.71 & 0.70 & 0.63 & 0.07 & 6.57 \\
\hline Average Education ( > 25 Years) & 4.91 & 3.86 & 1.05 & 6.68 & 4.85 & 3.93 & 0.92 & 5.72 \\
\hline$\%$ Garbage Collection & 76.85 & 65.47 & 11.38 & 4.45 & 75.95 & 66.36 & 9.58 & 3.70 \\
\hline \% Electric Lighting & 90.69 & 80.39 & 10.30 & 5.25 & 90.13 & 80.95 & 9.18 & 4.63 \\
\hline \% Piped Water & 80.35 & 61.19 & 19.16 & 6.65 & 79.20 & 62.34 & 16.85 & 5.74 \\
\hline Theil Index & 0.54 & 0.56 & -0.02 & -1.81 & 0.54 & 0.55 & -0.01 & -0.96 \\
\hline \multicolumn{9}{|l|}{ Employment: } \\
\hline Mining & 768.50 & 355.59 & 412.91 & 2.59 & 766.34 & 357.74 & 408.60 & 2.56 \\
\hline Agriculture & 14944.23 & 13569.76 & 1374.47 & 0.48 & 15729.87 & 12790.02 & 2939.85 & 1.02 \\
\hline Commerce & 31148.07 & 14404.79 & 16743.29 & 1.83 & 31453.90 & 14101.26 & 17352.64 & 1.90 \\
\hline Construction & 15586.88 & 7110.56 & 8476.32 & 1.93 & 15705.95 & 6992.39 & 8713.56 & 1.98 \\
\hline Finance & 3872.97 & 1219.33 & 2653.64 & 1.71 & 3882.99 & 1209.38 & 2673.61 & 1.72 \\
\hline Fishing & 447.04 & 356.71 & 90.33 & 0.76 & 447.56 & 356.21 & 91.35 & 0.77 \\
\hline Manufacturing & 21031.03 & 7456.24 & 13574.79 & 1.99 & 21017.92 & 7469.25 & 13548.67 & 1.99 \\
\hline - Chemicals & 2316.70 & 559.61 & 1757.09 & 1.59 & 2339.70 & 536.78 & 1802.92 & 1.64 \\
\hline - Electrical Equipment & 1824.77 & 244.13 & 1580.64 & 1.88 & 1824.14 & 244.75 & 1579.38 & 1.88 \\
\hline - Food & 5149.95 & 1943.45 & 3206.51 & 2.37 & 5075.14 & 2017.70 & 3057.43 & 2.25 \\
\hline - Furniture & 2136.22 & 755.13 & 1381.09 & 2.15 & 2098.05 & 793.01 & 1305.04 & 2.03 \\
\hline - Leather & 319.26 & 90.69 & 228.57 & 1.48 & 315.89 & 94.04 & 221.85 & 1.44 \\
\hline - Machinery & 1512.36 & 285.29 & 1227.08 & 2.20 & 1508.46 & 289.16 & 1219.30 & 2.18 \\
\hline - Metal & 6787.52 & 1383.30 & 5404.21 & 2.12 & 6753.26 & 1417.30 & 5335.95 & 2.09 \\
\hline - Paper & 792.21 & 151.46 & 640.75 & 1.98 & 799.22 & 144.50 & 654.72 & 2.03 \\
\hline - Petroleum & 322.19 & 161.65 & 160.54 & 0.87 & 322.65 & 161.19 & 161.46 & 0.87 \\
\hline - Plastics & 1603.60 & 233.59 & 1370.00 & 1.58 & 1600.83 & 236.34 & 1364.49 & 1.57 \\
\hline - Printing & 1774.79 & 399.12 & 1375.67 & 1.60 & 1782.72 & 391.25 & 1391.47 & 1.62 \\
\hline - Textiles & 5740.84 & 1642.37 & 4098.47 & 1.89 & 5775.75 & 1607.72 & 4168.03 & 1.92 \\
\hline - Tobacco & 174.45 & 50.79 & 123.67 & 1.19 & 173.58 & 51.66 & 121.91 & 1.17 \\
\hline - Transportation Equipment & 2743.73 & 581.56 & 2162.18 & 1.70 & 2704.30 & 620.69 & 2083.61 & 1.64 \\
\hline - Wood Products & 1288.22 & 766.84 & 521.38 & 1.76 & 1289.27 & 765.79 & 523.48 & 1.77 \\
\hline
\end{tabular}


Table 9(i) - Other Determinants of Entry Behavior

\begin{tabular}{|c|c|c|c|c|c|c|c|c|}
\hline & \multicolumn{4}{|c|}{ Medical, Veterinary, \& Dentistry Services } & \multicolumn{4}{|c|}{ Education Services } \\
\hline & Mean (High) & Mean (Low) & Difference & t-statistic & Mean (High) & Mean (Low) & Difference & t-statistic \\
\hline Population & 469430.10 & 281666.18 & 187763.92 & 1.25 & 495177.84 & 256112.03 & 239065.81 & 1.59 \\
\hline Transportation Cost & 1287.46 & 1624.40 & -336.93 & -2.61 & 1335.77 & 1576.45 & -240.68 & -1.85 \\
\hline Human Development Index & 0.69 & 0.65 & 0.04 & 3.59 & 0.69 & 0.64 & 0.05 & 4.54 \\
\hline Average Education ( > 25 Years) & 4.65 & 4.12 & 0.53 & 3.16 & 4.72 & 4.05 & 0.67 & 4.08 \\
\hline$\%$ Garbage Collection & 73.51 & 68.78 & 4.73 & 1.79 & 74.18 & 68.12 & 6.06 & 2.31 \\
\hline$\%$ Electric Lighting & 87.80 & 83.26 & 4.55 & 2.22 & 88.09 & 82.97 & 5.13 & 2.52 \\
\hline$\%$ Piped Water & 75.42 & 66.09 & 9.34 & 3.05 & 75.84 & 65.67 & 10.18 & 3.33 \\
\hline Theil Index & 0.55 & 0.55 & 0.00 & -0.25 & 0.55 & 0.55 & 0.00 & 0.14 \\
\hline \multicolumn{9}{|l|}{ Employment: } \\
\hline Mining & 666.62 & 456.71 & 209.90 & 1.30 & 681.59 & 441.85 & 239.74 & 1.49 \\
\hline Agriculture & 14115.25 & 14392.50 & -277.26 & -0.10 & 17067.28 & 11462.67 & 5604.61 & 1.96 \\
\hline Commerce & 28073.17 & 17456.57 & 10616.60 & 1.16 & 30079.71 & 15465.11 & 14614.60 & 1.60 \\
\hline Construction & 14109.64 & 8576.70 & 5532.95 & 1.25 & 14629.86 & 8060.39 & 6569.47 & 1.49 \\
\hline Finance & 3469.74 & 1619.53 & 1850.21 & 1.19 & 3732.35 & 1358.89 & 2373.46 & 1.52 \\
\hline Fishing & 385.08 & 418.21 & -33.14 & -0.28 & 464.44 & 339.45 & 124.99 & 1.05 \\
\hline Manufacturing & 18558.80 & 9909.88 & 8648.92 & 1.26 & 19126.81 & 9346.14 & 9780.67 & 1.43 \\
\hline - Chemicals & 2289.85 & 586.25 & 1703.60 & 1.55 & 2088.69 & 785.90 & 1302.79 & 1.18 \\
\hline - Electrical Equipment & 1759.01 & 309.39 & 1449.62 & 1.72 & 1646.49 & 421.06 & 1225.43 & 1.45 \\
\hline - Food & 4309.66 & 2777.42 & 1532.23 & 1.12 & 4647.19 & 2442.43 & 2204.76 & 1.62 \\
\hline - Furniture & 1788.87 & 1099.87 & 689.01 & 1.06 & 1989.21 & 901.03 & 1088.18 & 1.69 \\
\hline - Leather & 181.51 & 227.41 & -45.90 & -0.30 & 314.77 & 95.14 & 219.63 & 1.42 \\
\hline - Machinery & 1363.04 & 433.49 & 929.55 & 1.66 & 1311.92 & 484.23 & 827.69 & 1.47 \\
\hline - Metal & 6244.34 & 1922.39 & 4321.95 & 1.69 & 5555.41 & 2606.15 & 2949.26 & 1.15 \\
\hline - Paper & 738.81 & 204.46 & 534.35 & 1.65 & 672.73 & 270.05 & 402.68 & 1.24 \\
\hline - Petroleum & 278.39 & 205.12 & 73.27 & 0.39 & 282.74 & 200.80 & 81.95 & 0.44 \\
\hline - Plastics & 1460.04 & 376.08 & 1083.96 & 1.24 & 1442.48 & 393.50 & 1048.99 & 1.20 \\
\hline - Printing & 1616.00 & 556.71 & 1059.29 & 1.23 & 1693.58 & 479.71 & 1213.87 & 1.41 \\
\hline - Textiles & 5463.92 & 1917.20 & 3546.72 & 1.63 & 4902.08 & 2474.83 & 2427.25 & 1.11 \\
\hline - Tobacco & 71.71 & 152.76 & -81.05 & -0.78 & 174.46 & 50.78 & 123.68 & 1.19 \\
\hline - Transportation Equipment & 2708.68 & 616.35 & 2092.34 & 1.65 & 2357.99 & 964.40 & 1393.59 & 1.09 \\
\hline - Wood Products & 1171.95 & 882.24 & 289.71 & 0.98 & 1352.39 & 703.15 & 649.25 & 2.20 \\
\hline
\end{tabular}


Figure 1: Brazilian Monthly Per Capita Income Distribution

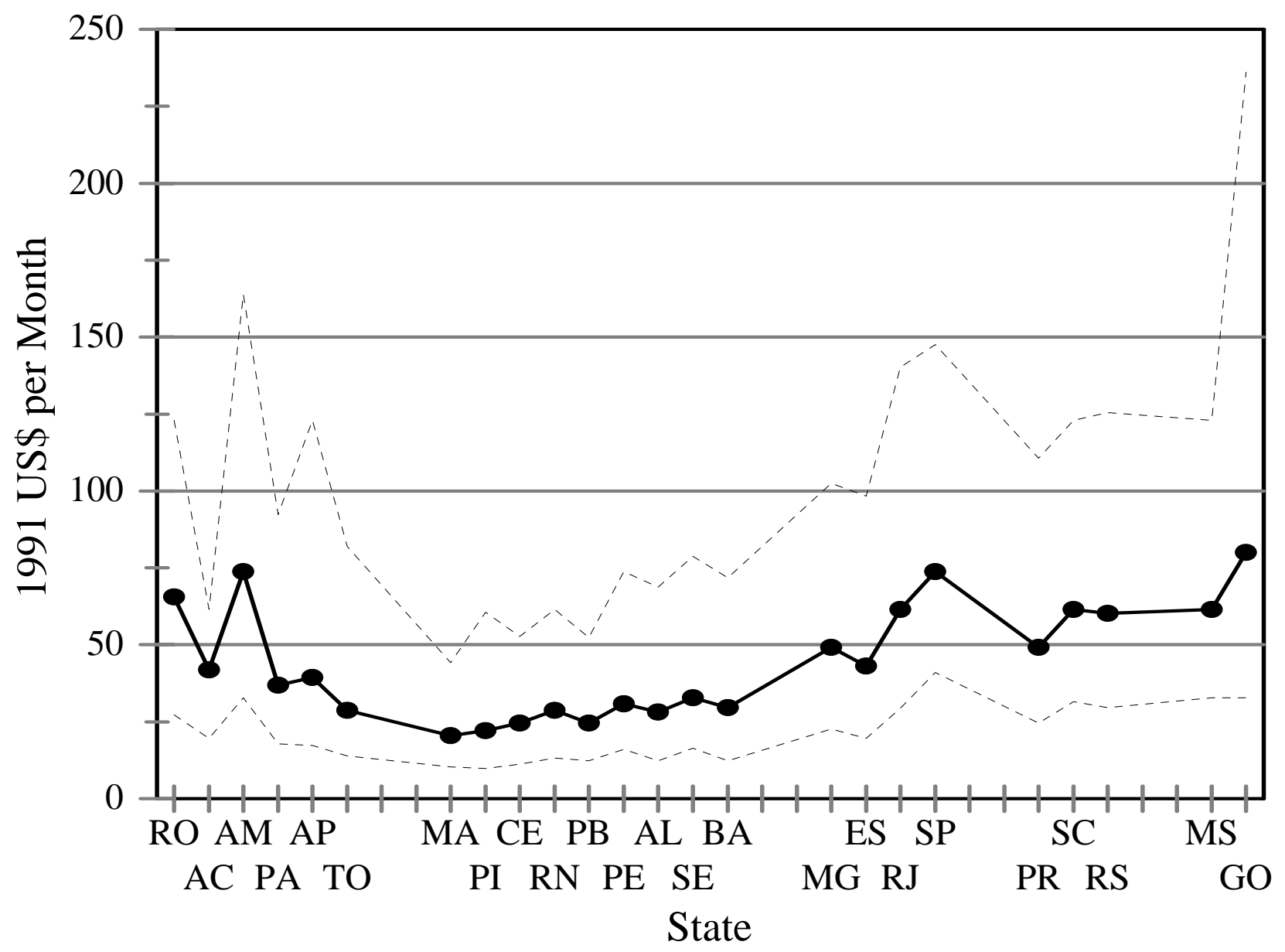


